Review

\title{
Integrins and bone metastasis: Integrating tumor cell and stromal cell interactions
}

\author{
Jochen G. Schneider ${ }^{\text {b,c }}$, Sarah R. Amend ${ }^{\text {a }}$, Katherine N. Weilbaecher ${ }^{\text {a,* }}$ \\ a Department of Medicine and Division of Oncology, Washington University, School of Medicine, St. Louis, MO, USA \\ ${ }^{\mathrm{b}}$ Institute for Clinical Biochemistry and Pathobiochemistry, University of Wuerzburg, Germany \\ ${ }^{c}$ Luxembourg Centre for Systems Biomedicine (LCSB), University of Luxembourg, Luxembourg
}

\section{A R T I C L E I N F O}

\section{Article history:}

Received 31 August 2010

Accepted 4 September 2010

Available online 17 September 2010

Edited by: T. Jack Martin

\section{Keywords:}

Integrins

Bone metastasis

Osteoclasts

Endothelium

Platelets

Cancer therapy

\begin{abstract}
A B S T R A C T
Integrins on both tumor cells and the supporting host stromal cells in bone (osteoclasts, new blood vessels, inflammatory cells, platelets and bone marrow stromal cells) play key roles in enhancing bone metastasis. Tumor cells localize to specific tissues through integrin-mediated contacts with extracellular matrix and stromal cells. Integrin expression and signaling are perturbed in cancer cells, allowing them to "escape" from cell-cell and cell-matrix tethers, invade, migrate and colonize within new tissues and matrices. Integrin signaling through $\alpha \mathrm{V} B 3$ and VLA- 4 on tumor cells can promote tumor metastasis to and proliferation in the bone microenvironment. Osteoclast $(\mathrm{OC})$ mediated bone resorption is a critical component of bone metastasis and can promote tumor growth in bone and $\alpha \mathrm{v} \beta 3$ integrins are critical to OC function and development. Tumors in the bone microenvironment can recruit new blood vessel formation, platelets, pro-tumor immune cells and bone marrow stromal cells that promote tumor growth and invasion in bone. Integrins and their ligands play critical roles in platelet aggregation ( $\alpha \mathrm{v} \beta 3$ and $\alpha \mathrm{IIb} \beta 3$ ), hematopoietic cell mobilization (VLA-4 and osteopontin), neoangiogenesis ( $\alpha v \beta 3, \alpha v \beta 5, \alpha 6 \beta 4$, and $\beta 1$ integrin) and stromal function (osteopontin and VLA-4). Integrins are involved in the pathogenesis of bone metastasis at many levels and further study to define integrin dysregulation by cancer will yield new therapeutic targets for the prevention and treatment of bone metastasis.
\end{abstract}

(c) 2010 Elsevier Inc. All rights reserved.

\section{Contents}

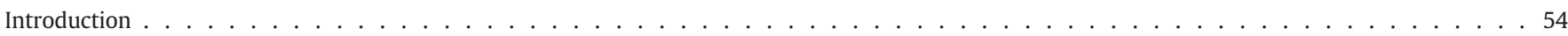

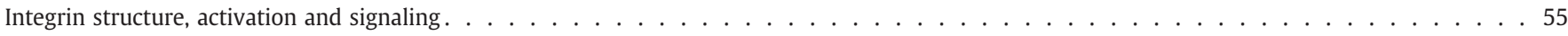

Integrin expression and signaling on tumor cells that metastasize to bone . . . . . . . . . . . . . . . . . . . . . . . . . . . . . . 56

Integrin expression and signaling in osteoclast function and bone metastasis. . . . . . . . . . . . . . . . . . . . 56

Integrins and tumor neovasculature and bone metastasis . . . . . . . . . . . . . . . . . . . . . . . . . . . . . .

Integrin-hematopoietic cell interactions: tumor-induced mobilization and modulation of bone marrow cells . . . . . . . . . . . . . . . . . 58

Integrins and tumor cell homing/colonization of bone . . . . . . . . . . . . . . . . . . . . . . . . . 58

Integrins and myeloid/immune cell function during tumor growth in bone . . . . . . . . . . . . . . . . . . . . 59

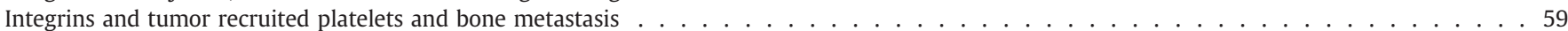

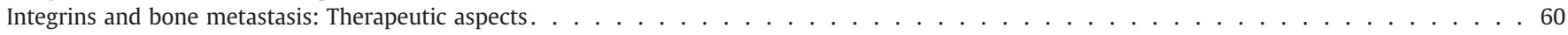

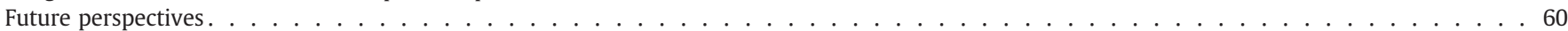

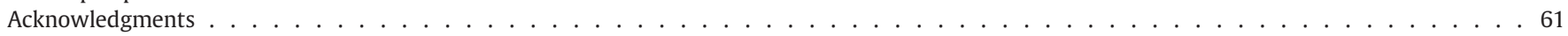

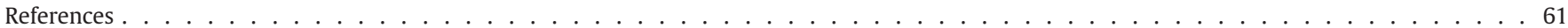

* Corresponding author. Department of Medicine and Cell Biology and Physiology, Division of Oncology, Washington University, School of Medicine, 660 S. Euclid Ave, PO Box 8069, St. Louis, MO, 63110, USA.

E-mail address: kweilbae@wustl.edu (K.N. Weilbaecher).

\section{Introduction}

The development of bone metastasis is common in many cancers, occurring in virtually all patients with multiple myeloma, in 65\%-75\% of patients with advanced breast and prostate cancers, and in 30\%$40 \%$ of patients with lung cancer [1-3]. The consequences of bone metastases are often devastating and can cause pain, pathologic 
fractures, spinal cord and other nerve-compression syndromes and life-threatening hypercalcemia [4]. Both osteolytic lesions and osteoblastic bone metastases are associated with increased OC activity and disrupted bone micro-architecture $[5,6]$. In the bone microenvironment, tumor cells secrete soluble factors that promote bone remodeling resulting in the release of additional bone matrix-bound growth factors which further activate OCs and osteoblasts (OB) and promote tumor growth [3,4,7-16]. Anti-resorptive therapy, e.g. with bisphosphonates or denosumab, significantly decreases skeletal complications of cancer and is a standard of care for patients with bone metastases [4,8,17-19]. In addition to their effects on bone, tumors in the bone microenvironment recruit blood vessel formation, platelets, immune cells and stromal cells that promote tumor growth and invasion in bone. Integrin-mediated cell signaling plays a critical role in many of these processes during bone metastasis, including platelet aggregation $(\alpha \mathrm{IIb} \beta 3)$, hematopoietic/immune cell mobilization (VLA-4 and osteopontin), neoangiogenesis $(\alpha \mathrm{v} \beta 3, \alpha \mathrm{v} \beta 5, \alpha 6 \beta 4$, and $\beta 1$ integrin) and stromal function (osteopontin and VLA-4) (see Fig. 1). For these reasons, the mechanisms by which integrin signaling mediates the pathogenesis of bone metastasis have been an area of active research.

\section{Integrin structure, activation and signaling}

Integrins are heterodimeric transmembrane glycoproteins that facilitate cell-cell and cell-extracellular matrix (ECM) adhesion and cell migration [20]. Integrins recruit many intracellular signaling molecules and can activate survival, proliferation, and motility signaling pathways [21]. There are 8 beta and 18 alpha integrin subunits that assemble into 24 unique known combinations in different cell types, each characterized by distinct ligand binding specificities (including collagen, osteopontin, fibronectin, laminin, and others, depending on the integrin family), signaling abilities, and regulatory mechanisms [22]. Integrins are activated by conformational changes in the integrin extracellular domains. When the integrin $\alpha$ and $\beta$ subunit cytoplasmic and transmembrane domains remain closely juxtaposed, the extracellular domains are held in a closed conformation. Activation by intracellular signals to the cytoplasmic tails results in separation of the $\alpha$ and $\beta$ cytoplasmic and transmembrane domains and exposure of the extracellular ligand binding domain [23] (inside-out signaling). The open conformation, facilitates high affinity ligand binding and triggers integrin-mediated cell signaling cascades (outside-in signaling) [24,25].

Many proteins play critical roles in the activation of specific integrins, but two cytoplasmic proteins, talin and kindlin, are necessary for inside-out signaling required for the activation of all integrin subtypes [23,26-29]. Talin binds to the proximal end of the beta cytoplasmic tail via a phosphotyrosine-binding (PTB) domain within its FERM domain [27] and links the integrin to the actin cytoskeleton [23]. Kindlin 1, 2, or 3, is necessary for talin-induced integrin activation $[26,30,31]$. Kindlin, like talin, also interacts with intracellular proteins resulting in cytoskeleton reorganization and adhesion [32]. G-protein coupled receptors such as the ADP receptor P2Y12, also play critical roles in the inside-out signaling required for integrin activation [25,33,34]. Structure-function analyses on $\beta 3$ integrins have shown that a membrane-proximal region is important for inside-out signaling [28,35-40].

In addition to activation by inside-out signaling, ligand binding and integrin clustering can be significantly modulated by growth factor receptor interactions and other integrin interacting proteins, as reviewed in $[22,23,41]$. For example, integrin associated protein, CD47, augments integrin activation and affects the ability of $\alpha v \beta 3$ integrin to cluster upon ligand binding [42]. Ligation of the integrin then stimulates outside-in signaling that leads to the activation of numerous signals critical for growth, migration, survival and other functions, including FAK phosphorylation, ERK signaling, and NF- $\kappa B$ activation. Thus, integrin signaling in cancer cells and in associated stromal, endothelial and hematopoietic cells can be influenced by intracellular signaling proteins, growth factors, chemokines and other receptors that participate in regulating integrin function through effects on integrin activation, ligand binding, ligand affinity and integrin clustering.

Maintaining adhesion to the ECM, in part through integrin signaling, is critical to cell survival [43]. Altered cell-cell or cellECM interactions results in disruption of downstream survival signaling and anchorage-dependent non-transformed cells undergo anoikis [43]. Under normal conditions, because each cell type expresses a unique set of integrins that recognize underlying ECM ligands, this form of apoptosis ensures that detached cells do not colonize inappropriate locations [43]. Cells that resist anoikis, such as metastatic cells, take advantage of several different mechanisms so

\section{Integrin Expression During Bone Metastasis}

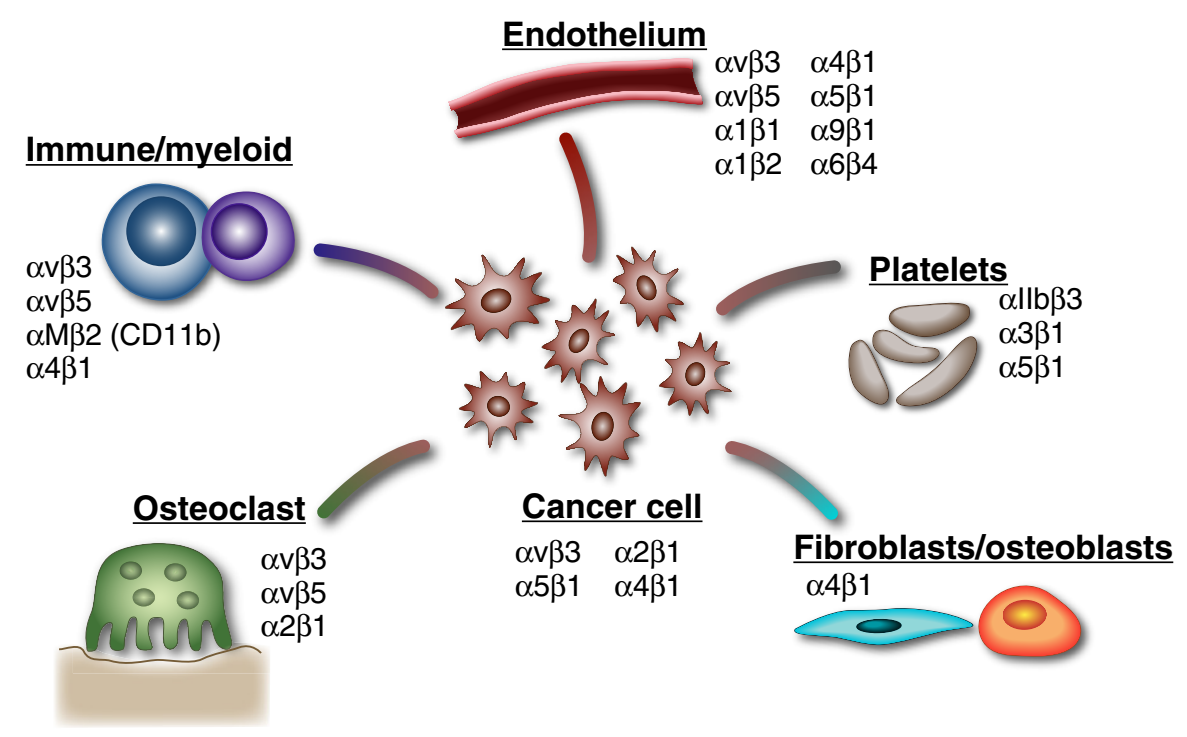

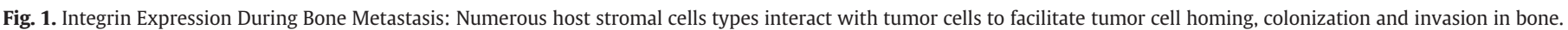
Preclinical and clinical evidence demonstrate that specific integrin expression and signaling on both tumor cells and host cells are central to facilitating bone metastasis. 
that the cell can adhere to a novel ECM, including aberrant integrin expression [44], constitutive activation of molecules usually activated via integrin signaling including FAK [45], EGFR [46] and SRC [47], and lack of activation of pro-apoptotic pathways [48], among others.

The integrin family of adhesion receptors links ECM to the cytoskeleton through a complex and regulated network of activation, interaction with numerous growth factor, GPCR, chemokine and cytokine receptors and induction of complex signaling cascades.

\section{Integrin expression and signaling on tumor cells that metastasize to bone}

Tumor progression, invasion and eventual metastasis require the activity of many adhesion proteins, including the integrin superfamily. At each stage of cancer progression, subsets of integrin heterodimers are activated, providing the necessary signaling pathways for adhesion, migration and cell survival. Metastatic tumor cells show differential integrin heterodimerization and activation compared to non-metastatic tumor cells that enable the cell to home to and colonize in a metastatic site, such as the bone marrow cavity $[49,50]$. In order for primary epithelial cancers to metastasize, the tumor cells must become resistant to anoikis and detach from the primary tumor site ECM, enter the vasculature, and eventually colonize a distant site. Upon reaching a successful metastatic site, however, tumor cells use both anoikis and anoikis-resistance to their advantage, in some cases forming micro-metastases that are resistant to cancer treatment via integrin binding to the underlying bone ECM as reviewed in [51]. Tumor cells must also form interactions between the tumor cell and bone stroma to establish and maintain skeletal metastasis. Many integrins have been implicated in tumor cell-host bone stroma interactions during bone metastasis and tumor growth in bone (Fig. 1, Table 1 ), including the $\beta 1$ and $\beta 3$ integrin family members.

av $\beta 3$ is a receptor for osteopontin, fibronectin, and vitronectin, ECM proteins that are important bone matrix proteins, and $\alpha \mathrm{v} \beta 3$ has been identified as a critical integrin in breast cancer and prostate cancer skeletal metastasis [50,52-56]. Interestingly, although $\alpha \mathrm{v} \beta 3$ has been shown to bind to fibronectin in other locations with high affinity, tumor $\alpha v \beta 3$ integrins do not bind fibronectin in bone marrow stroma, indicating that $\alpha \mathrm{v} \beta 3$-expressing tumor cells bind to the bone stromal ligands vitronectin and osteopontin [57]. In breast cancer, $\alpha v \beta 3$ binding of host osteopontin is necessary for tumor cell colonization to bone [58]. Bone metastatic cells have a higher expression of $\alpha v \beta 3$ than the primary tumor [53], promoting adherence to the bone matrix by binding osteopontin expressed by bone stromal cells [58]. Breast cancer cells that overexpress $\alpha v \beta 3$ have increased levels of bone metastasis and associated tumor burden and osteolysis [52,59-62]. This overexpression of $\alpha v \beta 3$ in the tumor cells leads to increased tumor cell adhesion, migration and invasion to bone as well as enhanced $\mathrm{OC}$ recruitment within the bone microen-

\section{Table 1}

Extracellular matrix proteins and the main integrins that participate in bone metastasis and tumor growth in bone.

\begin{tabular}{ll}
\hline Integrin & ECM ligands \\
\hline$\alpha v \beta 3$ & Vitronectin, osteopontin, bone sialoprotein, fibronectin, TSP-1 \\
$\alpha 2 \beta 1$ & Collagen I, laminin \\
$\alpha 4 \beta 1$ (VLA-4) & VCAM-1 fibronectin, osteopontin \\
$\alpha v \beta 1$ & Fibronectin, vitronectin \\
$\alpha v \beta 5$ & Vitronectin, osteonectin, bone sialoprotein, fibronectin \\
$\alpha I I b \beta 3$ & Fibrinogen \\
$\beta 2$ & VCAM-1, ICAM-1, fibrinogen \\
$\alpha 1 \beta 1$ & Collagen \\
$\alpha 5 \beta 1$ & Fibronectin \\
$\alpha 9 \beta 1$ & TSP1 \\
$\alpha 6 \beta 4$ & Laminin, TSP-1 \\
\hline
\end{tabular}

vironment [60,61], implicating a role of tumor-specific $\alpha \mathrm{v} \beta 3$ expression in breast cancer metastasis to bone as well as tumorassociated osteolysis. Likewise, in prostate cancer cells, active $\alpha \mathrm{v} \beta 3$ is necessary for the adherence and migration to bone matrix proteins at early stages of skeletal metastasis. This tumor cell $\alpha v \beta 3$ integrin expression allows cancer cells to adhere to the bone matrix and interact directly with the native bone cells, OBs and OCs, as well as with the bone matrix itself [59].

The $\beta 1$ family member, $\alpha 5 \beta 1$, has been identified as the primary integrin receptor for fibronectin on human bone marrow stroma [57]. $\alpha 5 \beta 1$ expression on leukemia, prostate and breast cancer cells facilitates interaction with bone stroma [57,63-65]. Antibody inhibition of $\alpha 5, \beta 1$ or fibronectin blocks prostate cancer tumor cell binding to bone stroma, indicating necessary roles for both integrin $\alpha 5 \beta 1$ on tumor cells and fibronectin on bone marrow stromal cells [57]. In breast cancer skeletal metastasis, the interaction between malignant cell $\alpha 5 \beta 1$ and host stromal cell fibronectin contributes to the survival of growth-arrested tumor cells, a potential mechanism through which tumor cells can become sequestered and "dormant" within the bone marrow cavity and may later begin to proliferate to establish a skeletal metastasis [64]. Upon FGF-2 growth factor stimulation, breast cancer cells undergo growth arrest and up-regulate $\alpha 5 \beta 1$ expression. In most cases, these cells die, but cells that bind fibronectin via $\alpha 5 \beta 1$ and initiate cell survival signaling cascades survive [64].

Another $\beta 1$ family member, $\alpha 2 \beta 1$, a collagen type I receptor, is expressed by prostate tumor cells, and its activity promotes invasion and adherence to the bone stroma. The presence of collagen I, the most abundant protein in bone, significantly increases prostate epithelial cell adhesion in culture, and antibody inhibition of integrin subunits $\alpha 2$ and $\beta 1$ significantly inhibits tumor cell binding to stroma [66]. Hall et al. showed that a skeletal metastatic prostate cancer cell line, but not cell lines that are metastatic to other organs, binds to collagen I and that this collagen I binding is $\alpha 2 \beta 1$ dependent in vivo [67]. Interestingly, stromal expression of collagen I does not increase tumor growth, but instead promotes tumor cell migration [67]. Tumor cell $\alpha 2 \beta 1$ binding of host bone marrow stromal collagen I activates RhoC GTPase which instigates a signaling cascade responsible for cytoskeleton reorganization, migration, and, eventually, collagenstimulated invasion and preferential skeletal metastasis [68].

$\alpha 4 \beta 1 /$ vascular cell adhesion molecule-1 (VCAM-1) binding has been identified as important for cell-cell contact between $\alpha 4 \beta 1$ expressing myeloma cells and VCAM-1 expressing bone marrow stroma [69]. This interaction contributes to bone tumor growth, OC stimulation and resultant osteolysis [69,70]. Likewise, epithelial tumor cells ( $\mathrm{CHO}$ ) that overexpress $\alpha 4 \beta 1$ developed significantly more bone metastases than mice inoculated with $\mathrm{CHO}$ cells alone [71]. Bone metastases, but not other metastases, were inhibited by antibodies against $\alpha 4$ and/or VCAM-1, suggesting a role for $\alpha 4 \beta 1$ / VCAM-1 binding in the skeletal metastases of solid tumors [71]. The role of integrins and chemokine cross talk in tumor cell homing to bone will be discussed later. While many aspects of tumor-bone stromal interactions remain unknown, it is clear that specific interactions between tumor cell integrins and bone stromal cell ligands are essential for successful homing and metastasis to bone.

\section{Integrin expression and signaling in osteoclast function and bone metastasis}

Bone invading metastatic tumor cells co-opt integrin signaling pathways that enhance $\mathrm{OC}$ function and recruitment. As part of bone remodeling, OCs bind to the bone matrix, form an actin ring mediated sealing zone, secrete enzymes and acid to degrade bone, and then migrate to a new site. Each of these functions is regulated in part by integrins located on the membrane surface of the OC, interacting with neighboring cells and with the ECM [72]. 
Several integrins are involved in OC binding to bone, including $\alpha \mathrm{v} \beta 3$ (osteopontin, vitronectin, bone sialoprotein), $\alpha \mathrm{v} \beta 5$ (fibronectin), and $\alpha 2 \beta 1$ (collagen) [73,74]. Of these, $\alpha v \beta 3$ is the predominant integrin found on OCs, and antibody inhibition of $\alpha \mathrm{v} \beta 3$ inhibits OC attachment to the bone matrix as well as OC mediated bone resorption [75]. In addition, mice with targeted disruption of $\beta 3$ integrin $(\beta 3-/-)$ have defective OC function [76] and are protected from tumor-associated osteolysis [77]. $\alpha v \beta 3$ is responsible for mediating OC-bone recognition $[53,75,78,79]$ and subsequent attachment to the bone matrix $[75,80]$, signaling to create the characteristic resorptive ruffled membrane, regulation of OC spreading, and overall organization of the cytoskeleton [76,81]. Activation of $\alpha v \beta 3$ regulates OC adhesion and migration on osteopontin, important for OC polarization and bone resorption [82]. Osteopontin ligand binding of $\alpha v \beta 3$ causes a reduction of OC cytosolic calcium, inducing podosome formation and subsequent resorption [83]. In addition, $\alpha \mathrm{v} \beta 3$ is critical for the activation of c-Src, c-Cbl, and GTPases Rho and Rac, signaling that is necessary for the cytoskeletal reorganization important in OC function $[81,84,85]$.

OC targeted therapy is a standard of care for the treatment of bone metastasis and myeloma bone disease. Tumor cells recruit OCs resulting in bone destruction and pain $[3,86,87]$. Because of its known role in $\mathrm{OC}$ function and its high expression in skeletal metastatic tumors much research has focused on $\alpha v \beta 3$ integrin and its ligands. An important characteristic of $\alpha \mathrm{v} \beta 3$ mediated cell adhesion, both in OCs and tumor cells, is the requirement of osteopontin, an $\alpha v \beta 3$ ligand [58]. Osteopontin is a non-collagenous bone matrix protein that is produced by OBs, OCs, and macrophages and is found in the ECM adjacent to calcified bone [88-90]. Expression of osteopontin in both the tumor cell and in the bone microenvironment can promote skeletal metastasis [91,92]. Osteopontin-deficient mice have reduced bone metastasis and tumorinduced osteolysis than wild type controls in a mouse model of tumor metastasis using syngeneic B16 melanoma cells [93,94], confirming a role for host cell osteopontin expression during bone metastasis. Recombinant osteopontin induces cell migration of B16 cells that is inhibited by repressing the ERK/MAPK pathway, suggesting that the ERK/MAPK pathway regulates bone microenvironment osteopontin levels [91]. Overexpression of osteopontin in B16 melanoma cells increases cell proliferation and migration, indicating that the ligand also plays an important role in the tumor cell itself [91]. It has been demonstrated using a prostate cancer cell line overexpressing osteopontin that tumor cell osteopontin regulates MMP-9 secretion and the subsequent CD44/MMP-9 interaction, important for the migration of prostate cancer cells, contributing to metastatic potential [95]. Osteopontin-producing tumor cells enhance osteopontin production by OBs [96] and OCs [97], stimulating osteoclastogenesis, OC adherence, migration, and bone resorption via host $\alpha v \beta 3$ binding [88,98]. Osteopontin activation of $\alpha v \beta 3$ integrin leads to downstream activation of FAK, c-Src kinase, and Ras-ERK, among other signaling molecules, resulting in cytoskeletal reorganization, focal adhesion formation, basolateral membrane differentiation, and osteoclastic resorption [59,99].

CD47, integrin associated protein, is expressed constitutively and interacts with integrins, including $\alpha v \beta 3$, as part of inside-out signaling cascades and also operates in an integrin-independent manner. CD47 plays a role in OC and macrophage biology and CD47-/ - mice have decreased OC number and function [100,101] which can be rescued in vitro by inhibiting nitric oxide synthase [101]. CD47-/- mice have decreased bone metastases and tumorassociated osteolysis compared to wild type [101]. During the early stages of osteoclastogenesis, namely, macrophage fusion, CD47 binds with SIRP1 $\alpha$, a molecule that is transiently induced in myeloid cells and that likely participates in early fusion events [102]. In the event of tumor cell metastasis to bone, however, it has been reported that cancer cells may utilize this macrophage self-recognition signaling to fuse with macrophages [103], leading to mature OCs with tumor cell nuclei and subsequent overexpression of OC stimulation factors, thus leading to increased OC function [104].

These data underscore the importance of integrins, especially $\alpha v \beta 3$, and its adaptor proteins in OC biology and bone metabolism and point to the role of $\mathrm{OC}$ integrins in regulating growth of cancer cells in the bone.

\section{Integrins and tumor neovasculature and bone metastasis}

Tumor neovascularization is essential for tumor cell invasion and metastasis. Access to the host blood supply provides the tumor cells with nutrients and connects the tumor to the circulation, facilitating the dissemination of metastatic cells. The angiogenic process begins with the de-stabilization and de-differentiation of local vessels, followed by activation of endothelial cells (EC), EC migration and proliferation into the tumor ECM, and finally organization of ECs into functional vessels. The ability of tumor cells to activate the normally quiescent vasculature is proposed to be controlled by an "angiogenic switch" mechanism, whereby tumor or stromal cells induce changes in the relative balance of inducers (e.g. vascular endothelial growth factor (VEGF) or TGF $\beta$, PDGF, TNF $\alpha$, bFGF) and inhibitors (e.g. thrombospondin-1 [TSP-1]) of angiogenesis reviewed in [41,105-109]. Activated platelets, tumor cells, and fibroblasts secrete many of these pro-angiogenic factors. It has recently been appreciated that macrophage lineage cells play important roles in promoting tumor-associated angiogenesis [110-113]. Bone metastasis and bone residing tumors like myeloma also modify and recruit ECs to enhance neoangiogenesis [114,115].

Many integrin heterodimers have been implicated in tumorassociated angiogenesis $[41,105-109,116]$. The first integrin found to regulate angiogenesis, $\alpha v \beta 3$, is expressed at high levels on tumorassociated vasculature $[117,118]$ and tumor-associated angiogenesis can be inhibited by $\beta 3$ integrin neutralizing antibodies [119-122]. $\alpha v \beta 3$ has been specifically implicated in the angiogenesis associated with prostate cancer bone metastases; antibody inhibition of $\alpha v \beta 3$ decreases tumor-associated blood vessels in mice [123]. Interestingly, Reynolds et al. demonstrated enhanced (not reduced) tumorassociated angiogenesis in subcutaneous tumors in $\beta 3-/-$ mice [124]. Elevated levels of VEGFR2 were found on tumor-associated blood vessels in $\beta 3-/-$ mice, and a VEGFR2 inhibitor could block the enhanced blood vessel formation [125]. It should be noted that an inhibitor of integrin binding and signaling might have different consequences than loss of integrin expression. For example, apoptotic machinery is activated in certain cells expressing integrins that are not ligand-bound [126-129]. Recent reports that low dose integrin antagonists can increase tumor growth and angiogenesis while higher doses suppress tumor growth and angiogenesis [130] underscore the complexity of targeting $\beta 3$ integrins for angiogenesis and cancer therapy.

Another $\alpha v$ integrin, $\alpha v \beta 5$, also shows increased expression on tumor-associated vasculature, and $\alpha v \beta 5$ antibodies inhibit VEGFinduced tumor-associated angiogenesis [131]. In contrast, the $\beta 3 /$ $\beta 5-/-$ double knockout mice show enhanced tumor-associated angiogenesis, as was seen in $\beta 3-/-$ mice [125]. Several hypotheses have been proposed that reconcile the contradictory results involving the $\alpha \mathrm{v}$ integrin family that outline the roles of the integrins as pro-angiogenic, anti-angiogenic, and/or working through different pathways as reviewed in $[41,108]$. It is clear, however, that $\alpha \mathrm{v} \beta 3$ and $\alpha \mathrm{v} \beta 5$ have distinct roles in regulation of tumor-associated angiogenesis and associated metastasis. The bone targeted bisphosphonate, zoledronic acid, alters EC integrinmediated adhesion by reduced expression of $\alpha v \beta 3$ and $\alpha v \beta 5$ integrin on ECs in vitro in one observation [132]. This observation provides a possible mechanism for OC-independent anti-tumor 
actions for bisphosphonates that have been reported in animal models [133-135] and clinically [136-139]. Evaluation of the effects of bisphosphonates on integrin signaling in the tumorbone microenvironment is underway.

While much of the research in integrin-mediated angiogenesis has been focused on the $\alpha \mathrm{v}$ integrins, there is evidence that other heterodimers play a role in angiogenic regulation, particularly the $\beta 1$ and $\beta 4$ families. The $\beta 1$ integrin family $(\alpha 1 \beta 1, \alpha 2 \beta 1, \alpha 5 \beta 1$, and $\alpha 4 \beta 1$ ) has a critical role in angiogenesis with $\beta 1-/-$ mice having severe vascular defects. $\alpha 1 \beta 1$ (a collagen receptor) and $\alpha 2 \beta 1$ (a laminin receptor) have been shown to be important for mediating cell adhesion in VEGF-stimulated ECs [140]. In vivo, function-blocking antibodies to $\alpha 1$ and $\alpha 2$ significantly inhibited VEGF-induced angiogenesis, indicating a positive regulatory role for $\alpha 1 \beta 1$ and $\alpha 2 \beta 1$ expression in tumor-associated angiogenesis [141]. Genetic data further support a role for the integrin $\alpha 1 \beta 1$ as a positive regulator of angiogenesis as $\alpha 1$-deficient mice show reduced angiogenesis [142].

Fibronectin receptor $\alpha 5 \beta 1$ has also been implicated as a positive regulator of angiogenesis: $\alpha 5 \beta 1$ antagonists inhibit tumor-associated angiogenesis in mice by inhibition of EC migration and regulating proliferation and apoptosis $[143,144]$. Importantly, the $\alpha 5 \beta 1$ antagonists did not inhibit angiogenesis induced by VEGF, indicating that the integrin $\alpha 5 \beta 1$ (together with $\alpha \mathrm{v} \beta 3$ ) may act in a VEGF-independent pathway [144]. $\alpha 4 \beta 1$, together with its ligand, VCAM-1, expressed in vessel mural cells, plays an important role in adhesion of ECs and vascular smooth muscle cells during blood vessel formation [145]. Both anti- $\alpha 4 \beta 1$ antibodies and anti-VCAM-1 antibodies inhibit angiogenesis in vivo. Another integrin, laminin receptor $\alpha 6 \beta 4$ is reported to regulate several aspects of tumor angiogenesis. Genetic studies revealed that $\alpha 6 \beta 4$ promotes endothelial cell migration in culture; in addition, the integrin is involved in the translational regulation of VEGF, having a pro-angiogenic effect [146,147].

In many cases, integrins influence angiogenesis through their interaction with the integrin ligand thrombospondin 1 (TSP-1). Mice with a TSP-1 deficiency have increased tumor burden and tumorassociated vasculature, both in capillary size and number, while mice that overexpress TSP-1 have delayed or absent tumor growth and reduced tumor-associated vasculature [148]. These data indicate that TSP-1 can contribute to tumor burden via negative regulation of angiogenesis. In contrast, in a human breast cancer cell line, TSP-1 stimulation up-regulates both integrin subunit $\alpha 6$ mRNA levels and protein levels which leads to increased adhesion to ECM protein laminin in vitro, suggesting that TSP-1 facilitates pathogenic angiogenesis [149]. TSP- 1 also interacts with $\alpha 9 \beta 1$ via its N-terminal domain and has a positive effect on proliferation and motility in culture and on angiogenesis in vivo that can be reduced by $\alpha 9 \beta 1$ inhibitors. This binding of the microvasculature-associated integrin in ECs with TSP-1 activates signaling cascades including ERK and paxillin. Thus, TSP-1 can play both pro- and anti-angiogenic roles, depending on its specific integrin interaction.

The roles of integrins in tumor-associated angiogenesis are complex, not only involving integrin ligand interactions and associated signaling pathways, but also specific temporal regulation and indirect effects through proteins such as TSP-1, and are important for the progression of angiogenesis and eventual metastasis.

\section{Integrin-hematopoietic cell interactions: tumor-induced mobilization and modulation of bone marrow cells}

The bone marrow is the primary site of hematopoiesis in the adult. OBs and bone marrow stromal cells regulate hematopoietic stem cell (HSC) growth, differentiation and bone marrow retention through numerous signaling pathways including integrin VLA-4/VCAM [150], chemokine SDF-1/CXCR4, BMPs and Notch [151-156]. Hematopoietic progenitors and stem cells express the integrin VLA-4 and the chemokine receptor CXCR4. OB and bone marrow stromal cells produce VCAM-1, SDF-1 and osteopontin, all important components of the "HSC niche" [157-159]. Integrin and chemokine signaling work in concert to promote HSC and progenitor cell homing and mobilization in the bone marrow [160]. Disruption of VLA-4/VCAM1 and SDF-1/CXCR4 interactions results in mobilization of HSC into the circulation [159]. G-CSF mobilization of HSC acts in part through disruption of VLA-4/VCAM-1 and CXCR4/SDF1 interactions [158,161]. OC resorption can also regulate HSC mobilization and the stem cell niche [162].

Diverse integrins are expressed on hematopoietic progenitor cells in specific patterns and at distinct time points [163]. Integrins not only mediate the binding of normal progenitor cells to stroma and matrix molecules, but may also regulate expansion, maturation and differentiation of those cells [164,165]. For example, $\alpha 4 \beta 1$ integrin regulates hematopoietic progenitor cell fate through changes in integrin expression and activity levels during cell maturation and differentiation into erythrocytes and neutrophils [165-167]. $\alpha 4$ containing integrins mediate adhesion of hematopoietic progenitors to stromal cells likely through binding to matrix components such as fibronectin [168] or cellular receptors such as VCAM-1 [169]. The integrin subunits $\alpha 5, \alpha 6$ and $\alpha 9$ have also been shown to be expressed by progenitor cells [170-172]. Studies using blocking antibodies demonstrated that $\alpha 6$ subunit cooperates in collaboration with the $\alpha 4$ subunit in regulating the homing of progenitor cells [171]. $\alpha 9 \beta 1$ integrin is also important for adhesion of progenitor cells to OBs in the bone marrow [172], illustrating the fact that hematopoiesis takes place in three dimensional matrices, the so-called bone marrow niches. These niches are located at the endosteum near OBs and in the vascular niche close to marrow blood vessels [173].

Tumor cells both in the bone microenvironment and at distant sites can modulate and mobilize hematopoietic progenitor and immune cells to promote bone and visceral metastasis and local tumor growth. Tumor-induced mobilization of VEGFR + and Sca+kit-bone marrow derived cells has been implicated in enhancing distant tumor and metastatic growth [174]. These mobilized VEGFR + cells also express $\alpha 4 \beta 1$ and can migrate to sites of increased synthesis of matrix components such as fibronectin and establish a "pre-metastatic niche" that can favor tumor metastasis and growth [174]. $\beta 2$ integrins on bone marrow derived endothelial progenitors can also mediate the adhesion and VEGF-induced migration of the progenitors to the mature endothelium of actively remodeling vasculature [175].

Tumor cells from a primary lesion can act at a distance to influence bone marrow hematopoiesis through secreted factors such as the integrin ligand, osteopontin [176]. Primary epithelial tumors can instigate growth of indolent tumors through modulation of the bone marrow microenvironment and mobilization and recruitment of bone marrow cells to distant tumor sites [176,177]. McAllister et al. found that tumor secretion of osteopontin is necessary but not sufficient in xenograft models to modulate the bone microenvironment and promote bone marrow cell recruitment to tumor metastasis [176]. Pazolli et al. found that osteopontin secreted by senescent fibroblasts promoted tumorigenesis in animal models of skin cancer [178].

Thus tumors cells both in bone and at distant sites can modulate hematopoiesis in part through osteopontin and bone marrow cell integrins resulting in the mobilization and recruitment of bone marrow derived cells that will enhance local and metastatic tumor growth.

\section{Integrins and tumor cell homing/colonization of bone}

The site of metastasis is tumor cell specific depending on their integrin, chemokine receptor and cytokine/receptor expression profiles [50,179-181]. At the metastatic site, normal physiology is changed towards increased secretion of cytokines and activation of integrins to support recruitment, survival and growth of tumor cells. 
Metastasizing cancer cells can co-opt the same mechanisms used in physiological hematopoietic progenitor cell homing to bone through expression of integrins and chemokines [150,152,153]. CXCR4 expressed on cancer cells can direct those cells to bone [181-186]. The migration of myeloma cells to and across bone marrow stromal cells is in part regulated by SDF- $1 \alpha /$ CXCR4 ligation and up-regulation of $\alpha 4 \beta 1$ (VLA-4) results in adhesion of myeloma cells to the underlying bone marrow stroma [187]. Likewise, CXCR4 ligation can increase $\alpha v \beta 3$ expression and aggressiveness of metastatic prostate cancer cells, and disruption of CXCR4 can inhibit prostate cancer bone metastases [183-185].

It has recently been shown that $\beta 3$ integrin activity on circulating CXCR4-positive bone marrow derived cells is important for their migration and recruitment to sites of angiogenesis. In mice with mutated tyrosine residues "knocked in" to the $\beta 3$ integrin locus to inhibit proper phosphorylation (DiYF mice) [188], CXCR4-positive bone marrow derived cells were higher in number and defective in recruitment to subcutaneously implanted tumors or wounds, where SDF-1 levels were also lower [189]. These data demonstrate that $\beta 3$ integrin on bone marrow derived cells may be critical for the CXCR4/ SDF-1 gradient, and thus may be important for localization of tumor cells to the bone microenvironment and also localization of myeloid/ ECs to tumors. Interestingly, CXCR4 deletion on bone marrow cells can enhance OC activity which could counteract some of the beneficial effects of CXCR4 inhibition on bone metastases [9].

Integrins expressed by tumor cells, in concert with bone microenvironment chemokine secretion and further integrin activation, determine the osteotropic characteristics of metastasizing cancer cells and represent an ideal target for skeletal metastatic cancer therapy.

\section{Integrins and myeloid/immune cell function during tumor growth in bone}

Myeloid cell integrins are involved in tumor escape from immune responses and tumor-induced angiogenesis. Bone marrow derived myeloid cells (macrophages, monocytes, myeloid derived suppressor cells, and myeloid dendritic cells) migrate to tumors and contribute to tumor growth, invasion and angiogenesis [190-194]. Macrophages within tumors, called tumor-associated-macrophages (TAM) [127], are recruited by chemoattractants such as MCP-1 [195] secreted by the tumor and then differentiate into tissue macrophages [196]. The anti-tumor M1 phenotype represents a classical activation that is induced by pathogens, lipopolysaccharides (LPS) or interferon gamma resulting in secretion of proinflammatory cytokines such as tumor necrosis factor $\alpha$ (TNF $\alpha$ ), interleukin $1 \beta$ (IL-1 $\beta$ ) and others. M1 macrophages can act in an anti-tumor fashion by secretion of cytotoxic cytokines and antigen presentation to lymphocytes [197] The pro-tumor M2 phenotype, represents alternative activation induced by IL-4 or IL-10 [198]. M2 polarized macrophages promote tumor cell proliferation and survival, suppress immune responses and drive tumor neoangiogenesis [197,199-201]. Studies have shown that the TAM content of tumors and prognosis of patients are inversely correlated $[192,202,203]$.

$\beta 2$ integrins are involved in monocyte/myeloid cell migration through endothelium and in phagocytosis, while $\beta 1$ integrins mediate adhesion to matrix proteins and the induction of inflammatory genes [204]. $\alpha 4 \beta 1$ and $\alpha v \beta 3$ integrins have been implicated in myeloid cell homing, adhesion and migration to tumors. $\alpha 4 \beta 1$ promotes endothelial progenitor cells and monocyte homing and adhesion to sites of active pathological angiogenesis [205]. Inhibition of $\alpha 4 \beta 1$ leads to suppressed monocyte and macrophage colonization of tumors and associated vasculature and decreased angiogenesis [194].

The $\alpha v \beta 3$ integrin is down-regulated during differentiation of bone marrow myeloid progenitor cells to monocytes but induced in macrophages during inflammation [206,207]. $\alpha v \beta 3$ promotes myeloid homing, adhesion and migration of bone marrow derived cells through the endothelium to sites of tumor angiogenesis [189]. $\beta 3$ integrins are involved in phagocytosis of apoptotic cells [208,209] and limit the secretion of inflammatory mediators [207]. Defective macrophage tumor infiltration is observed in TAM from $33-/-$ bone marrow, myeloid specific $\beta 3 \mathrm{KOM}-/-$ mice and in the signaling defective DiYF $\beta 3$ mice (mice with two mutated tyrosine residues) [111,189,210-213], suggesting that defective cytoskeletal reorganization or lack of appropriately polarized macrophages [212] within tumors may be due to $\beta 3$ integrin deficiency.

Myeloid derived suppressor cells (MDSC) [214] represent a subpopulation of immature myeloid cells that are roughly characterized by GR1 + and by the $\alpha \mathrm{M} \beta 2(\mathrm{CD} 11 \mathrm{~b})$ integrin adhesion marker [214]. The MDSC suppress T-cell antigen receptor mediated immune responses [190] and can promote TAM M2 polarization [215]. MDSC from myeloma bearing mice had a greater capacity to become bone resorbing cells compared to MDSC from control mice [191]. The role of integrins in MDSC differentiation, recruitment and function is under investigation. Integrins are involved in monocyte/macrophage differentiation and recruitment to tumors and can influence local and metastatic tumor growth.

\section{Integrins and tumor recruited platelets and bone metastasis}

Cancer cells co-exist with platelets and mononuclear hematopoietic cells in thrombi located throughout the organs of patients with metastatic cancer [216-218]. Platelet aggregation and activation enhances tumor growth and metastasis to bone [77,219]. Platelets are anuclear metabolically active cells that are formed from bone marrow megakaryocytes. Platelet aggregation is stimulated by soluble factors such as ADP and thromboxane $\left(\mathrm{TXA}_{2}\right)$, membrane proteins, collagen or von Willebrand factor that are produced by injured endothelial, inflammatory and tumor cells. $\alpha \operatorname{IIb} \beta 3$ plays a central role in the initiation of arterial thrombosis and platelet aggregation $[220,221]$. $\alpha$ IIb $\beta 3$ integrins are expressed on the surface of megakaryocytes and platelets and are undetectable on any other noncancerous cell type. Mice globally deficient for the $\beta 3$ integrin have prolonged bleeding times, defects in platelet aggregation and clot retraction and cutaneous and gastrointestinal bleeding, all characteristics of Glanzmann's thrombasthenia, [222] a disease characterized by functional reduction or absence of $\alpha \operatorname{IIb} \beta 3$ in humans. Targeting $\beta 3$ integrins by monoclonal antibodies to the receptor (abciximab/ Reopro) or by inhibiting the binding of the ligand fibrinogen to the receptor (tirofiban/Integrilin) are used in patients with acute coronary and cerebral vascular syndromes but have significant bleeding risks that prevent their usefulness for chronic uses such as cancer.

Tumor cell lines have been shown to induce platelet aggregation and adhesion in vitro through mechanisms involving $\alpha$ IIb $\beta 3$ integrin, ADP, thrombin, von Willebrand factor and selectins [77,223-229]. The metastatic potential of tumor cell lines is markedly diminished in mice with defective platelet aggregation ( $\beta 3$ integrin $-/-$, Gaq-/-, Par4-/-, NFE2 -/- and fibrinogen -/-) [77,219,223,226,228-244]. $\mathrm{B3}-/-$ mice are protected from bone metastasis in part through a mechanism involving defective platelet aggregation [77]. Additionally, tumor cells engineered to respond to platelet-derived lysophosphatidic acid (LPA) have enhanced bone metastatic potential in mice [219]. Platelets also represent a significant source of pro-angiogenic (VEGF) and anti-angiogenic factors (TSP-1) and are recruited to tumor sites where their aggregation could affect local tumor growth [245]. Platelet-specific integrin targeting is a promising therapeutic approach for inhibiting bone metastasis, especially to prevent or slow metastasis.

In contrast to platelets, bone marrow megakaryocytes can inhibit prostate cancer tumor growth in bone [246]. Megakaryocytes can indirectly inhibit bone resorption by inhibiting OC formation [247]. The negative effect of megakaryocytes on bone resorption is likely 
mediated in part through the OC inhibitory factor osteoprotegrin that is contained in secretory granules of platelets and megakaryocytes $[248,249]$. Adhesion of mature polyploid megakaryocytes to fibronectin is also mediated by $\beta 1$ subunit containing integrins [250,251]. Megakaryocytes may also influence bone remodeling and resorption through effects on OB proliferation that are mediated by the $\alpha 3 \beta 1$, $\alpha 5 \beta 1$ and glycoprotein IIb integrins [252]. Given the location of mature megakaryocytes at vascular sinusoids, they are also among the first cells to physically encounter cancer cells as they enter the bone marrow, so a direct mechanism of action involving integrin-mediated signal transduction could be involved. Interestingly, bisphosphonates (BP) increase megakaryocyte proliferation and increase the platelet concentration of the anti-angiogenic integrin ligand TSP-1 [253-255] which suggests non-OC mechanisms of BPs' action in decreasing tumor growth in bone. Thus, platelets and their megakaryocytic precursors interact with cancer cells before, during and after metastasis to bone through interactions mainly determined by integrins and their ligands.

\section{Integrins and bone metastasis: Therapeutic aspects}

Because of the wide range of functions in physiological and pathological processes, the integrin family of adhesion receptors has been adopted as a promising target for metastatic bone diseases. Several tumor cell types express an abnormal integrin profile compared to non-tumor cells $[41,51,256]$, providing an opportunity for specific targeting. Targeting integrins on both tumor and/or host cells has proven to be effective not only in blocking local cancer progression, but also in reducing tumor cell detachment from their primary site in preclinical models [257-259].

In recent years, integrins on the tumor cells and the endothelium have been targeted by monoclonal antibodies and RGD peptides in order to reduce tumor angiogenesis $[109,260]$. Integrin antagonists, including humanized monoclonal antibodies, small molecule antagonists and cyclic peptides, have been developed based on the recognition sequences of integrin physiological ligands [261]. Several compounds are already in clinical use or undergoing their clinical evaluation for various diseases.

For the future treatment of skeletal metastasis, the $\alpha \mathrm{v} \beta 3$ integrin has become an attractive target because of its expression in tumor and angiogenic cells, its role in OC differentiation and function and its role in tumor cell homing to bone [53,60,61,183,262-267]. The multiple expected beneficial effects on endothelial, cancer and osteoclastic cells instigated a significant effort to develop drug candidates that target the $\alpha \mathrm{v} \beta 3$ integrin for therapy of skeletal complications of cancer. These strategies resulted predominantly in antagonists of $\alpha v \beta 3, \alpha v \beta 5$ and $\alpha I I \beta 3$ integrins that showed efficacy in animal models. Peptidomimentic antagonists of the $\alpha v \beta 3$ and $\alpha v \beta 5$ integrins were successfully used to inhibit $O C$ in vitro and to reduce bone loss in a rat osteoporosis model [268]. An active nonpeptide $\alpha v \beta 3$ integrin antagonist and anti- $\alpha v \beta 3$ antibodies were shown to hinder cancer induced bone loss [79,268-270]. It is possible that the current treatment for bone metastasis, BPs, may also exert an effect on $\alpha v \beta 3$ on both ECs [132] as well as OCs in a similar manner.

Many drugs candidates targeting integrin $\alpha \mathrm{v} \beta 3$ have advanced to the clinic for the treatment of osteoporosis and cancer, though none have specifically targeted patients with bone metastases. A lipophilic isoester of RGD (L000845704), developed by Merck, is effective in increasing bone mineral density (BMD) in postmenopausal women [271]. Another inhibitor, RGD-mimetic cyclic peptide Cilengitide (EMD-1219974) directed at both $\alpha v \beta 3$ and $\alpha v \beta 5$ [272] and currently investigated by MerckSerono, is in advanced stages of clinical testing for the treatment of glioblastoma multiforme and is under investigation for the treatment of squamous cell carcinoma, prostate cancer, and lung cancer (Phase II).
Clinical trials of function-blocking antibodies are also ongoing, including Vitaxin (LM609), a humanized monoclonal $\operatorname{IgG}_{1}$ antibody against the extracellular domain of the $\alpha v \beta 3$ integrin heterodimer. Vitaxin had substantial anti-angiogenic effects in preclinical models $[119,262]$ and has shown direct anti-tumor effects as well as impaired bone resorption by inhibiting $\mathrm{OC}$ attachment to the bone surface [273]. Another monoclonal antibody (CNTO95), directed against the $\alpha v$ subunit, is under development by Centocor and is in phases I-II testing for solid tumors. Two other additions to this therapeutic family are planned to be more specifically evaluated for their effects on bone metastasis [62], organic small molecule GLPG0187 [62] and peptide antagonist S247 [257].

Given the participation of the OCs, blood vessels and platelets in bone metastases, it may be beneficial to block both $\alpha \mathrm{v} \beta 3$ and $\alpha \mathrm{II} \beta 3$ integrins on host cells. This concept of combination inhibition relies on the common RGD ligand binding domains of $\alpha v \beta 3, \alpha v \beta 5$ and $\alpha$ IIb $\beta 3$. In fact, many of the synthetically designed $\alpha v \beta 3$ integrin inhibitors display some selectivity towards $\alpha \mathrm{v} \beta 5$ integrin, and, in the case of Cilengitide, this dual antagonism is part of the mechanism to treat cancer by inhibiting neoangiogenesis as well as invasion [274,275]. The strategy to combine multiple targets also bears some risks with regards to the desired high therapeutic specificity and low off-target toxicity. This issue is further complicated by the differential function of the integrins as determined by their location, expression level, activation status and ligand binding. Studies in animal models and xenograft tumor models have demonstrated that low concentrations of $\alpha \mathrm{v} \beta 3$ integrin antagonists can act as integrin agonists [130,276,277]. Further research is necessary to identify optimal drug dosing and targeting that overcome the problem of generalized integrin inhibition to reduce or prevent skeletal metastasis.

Another area of active research in bone metastasis therapeutics is the specific targeting of integrins on HSCs or progenitors that prepare the metastatic niche and enhance bone marrow colonization by cancer cells which then instigate the vicious cycle of bone metastasis [278,279]. Interfering with integrin-mediated homing of cancer cells to the cells to the bone represents an early option for intervention. siRNA against the $\alpha \mathrm{v}$ integrin subunit was used to prevent the progression of prostate cancer to bone by interfering with the ECM-integrin interaction [280]. In another approach, a disintegrin and a neutralizing antibody to VCAM-1 or its receptor $\alpha 4 \beta 1$ integrin reduced metastasis of melanoma cells and diminished osteolysis by decreasing OC activity in a myeloma in vitro model [69,281]. These strategies, however, are not yet in clinical trials. An exciting new approach to cancer therapy takes advantage of the fact that cancer cells use CXCR4 and VLA-4 to home to and engraft in the marrow. HSC mobilizing agents such as AMD3100 and anti-VLA-4 targeted agents can be used to mobilize leukemia and myeloma cells into the blood from the bone marrow leading to increased sensitivity to chemotherapy [282-284] in mice. This approach is now being tested in clinical trials.

\section{Future perspectives}

Despite the high level of complexity of the integrin family, the $\beta 3$ integrin remains a major target in the search for effective therapies for skeletal metastasis. In recent years, a steady increase in knowledge has led to clinical testing of several interesting compounds. There remains, however, a lack of clarity concerning the exact roles of the integrins in different cell types. In the initiated clinical studies using $\alpha v \beta 3$ integrin antagonists, the overall effect in reducing tumor growth and pathological angiogenesis in fast progressing deadly tumors may outweigh potential undesired effects in tissues or cells other than tumor or endothelial origin. Drugs designed to tackle skeletal complications of cancer must be targeted to the bone microenvironment. This fact is underscored by 
the clinical successes of the bone matrix targeted bisphosphonates and the $\mathrm{OC}$ targeted denosumab in treating and preventing skeletal complications of bone metastases and myeloma. A detailed understanding of the role of integrin regulation in both the metastatic tumor cells and the tumor-associated stroma will allow for a more targeted and focused approach to treat bone metastases.

\section{Acknowledgments}

The authors sincerely thank Dr. Michael Tomasson for his help, guidance and critical reading of this manuscript. This work was supported by the NIH-NIHR0152152 to KNW and by the St. Louis Men's group against cancer (SRA). JGS was supported by an IZKF start up grant from the University of Wuerzburg, Germany. SRA was also supported by the Lucille P. Markey Special Emphasis Pathway in Human Pathobiology at Washington University School of Medicine.

\section{References}

[1] Lipton A. Pathophysiology of bone metastases: how this knowledge may lead to therapeutic intervention. J Support Oncol 2004;2:205-13 [discussion 213-4, 216-7, 219-20].

[2] Coleman RE. Metastatic bone disease: clinical features, pathophysiology and treatment strategies. Cancer Treat Rev 2001;27:165-76.

[3] Mundy GR. Metastasis to bone: causes, consequences and therapeutic opportunities. Nat Rev Cancer 2002;2:584-93.

[4] Roodman GD. Mechanisms of bone metastasis. N Engl J Med 2004;350:1655-64.

[5] Lipton A, Costa L, Ali S, Demers L. Use of markers of bone turnover for monitoring bone metastases and the response to therapy. Semin Oncol 2001;28:54-9.

[6] Coleman RE, Major P, Lipton A, Brown JE, Lee KA, Smith M, et al. Predictive value of bone resorption and formation markers in cancer patients with bone metastases receiving the bisphosphonate zoledronic acid. J Clin Oncol 2005;23: 4925-35

[7] Guise TA, Mohammad KS, Clines G, Stebbins EG, Wong DH, Higgins LS, et al. Basic mechanisms responsible for osteolytic and osteoblastic bone metastases. Clin Cancer Res 2006;12:6213s-6s.

[8] Hirbe A, Morgan EA, Uluckan O, Weilbaecher K. Skeletal complications of breast cancer therapies. Clin Cancer Res 2006;12:6309s-14s.

[9] Hirbe AC, Rubin J, Uluckan O, Morgan EA, Eagleton MC, Prior JL, et al. Disruption of CXCR4 enhances osteoclastogenesis and tumor growth in bone. Proc Natl Acad Sci U S A 2007:104:14062-7.

[10] Bendre MS, Montague DC, Peery T, Akel NS, Gaddy D, Suva LJ. Interleukin8 stimulation of osteoclastogenesis and bone resorption is a mechanism for the increased osteolysis of metastatic bone disease. Bone 2003;33:28-37.

[11] Pfeilschifter J, D'Souza SM, Mundy GR. Effects of transforming growth factor-beta on osteoblastic osteosarcoma cells. Endocrinology 1987;121:212-8.

[12] Kozlow W, Guise TA. Breast cancer metastasis to bone: mechanisms of osteolysis and implications for therapy. J Mammary Gland Biol Neoplasia 2005;10:169-80.

[13] Kingsley LA, Fournier PG, Chirgwin JM, Guise TA. Molecular biology of bone metastasis. Mol Cancer Ther 2007;6:2609-17.

[14] Clines GA, Guise TA. Molecular mechanisms and treatment of bone metastasis. Expert Rev Mol Med 2008;10:e7.

[15] Yin JJ, Selander K, Chirgwin JM, Dallas M, Grubbs BG, Wieser R, et al. TGF-beta signaling blockade inhibits PTHrP secretion by breast cancer cells and bone metastases development. J Clin Invest 1999;103:197-206.

[16] Kakonen SM, Selander KS, Chirgwin JM, Yin JJ, Burns S, Rankin WA, et al Transforming growth factor-beta stimulates parathyroid hormone-related protein and osteolytic metastases via Smad and mitogen-activated protein kinase signaling pathways. J Biol Chem 2002;277:24571-8.

[17] Hamdy NA. Denosumab: RANKL inhibition in the management of bone loss. Drugs Today (Barc) 2008;44:7-21.

[18] Body JJ, Lipton A, Gralow J, Steger GG, Gao G, Yeh H, et al. Effects of denosumab in patients with bone metastases, with and without previous bisphosphonate exposure. J Bone Miner Res 2009.

[19] Fizazi K, Lipton A, Mariette X, Body JJ, Rahim Y, Gralow JR, et al. Randomized phase II trial of denosumab in patients with bone metastases from prostate cancer, breast cancer, or other neoplasms after intravenous bisphosphonates. J Clin Oncol 2009;27:1564-71.

[20] Schwartz MA, Schaller MD, Ginsberg MH. Integrins: emerging paradigms of signal transduction. Annu Rev Cell Dev Biol 1995;11:549-99.

[21] Hynes RO. Integrins: versatility, modulation, and signaling in cell adhesion. Cell 1992:69:11-25.

[22] Hynes RO. Integrins: bidirectional, allosteric signaling machines. Cell 2002;110: 673-87.

[23] Shattil SJ, Kim C, Ginsberg MH. The final steps of integrin activation: the end game. Nat Rev Mol Cell Biol 2010;11:288-300.

[24] Qin J, Vinogradova O, Plow EF. Integrin bidirectional signaling: a molecular view. PLoS Biol 2004;2:e169.

[25] Offermanns S. Activation of platelet function through G protein-coupled receptors. Circ Res 2006;99:1293-304.
[26] Ma YQ Oin J, Wu C, Plow EF. Kindlin-2 (Mig-2): a co-activator of beta3 integrins. J Cell Biol 2008:181:439-46.

[27] Tadokoro S, Shattil SJ, Eto K, Tai V, Liddington RC, de Pereda JM, et al. Talin binding to integrin beta tails: a final common step in integrin activation. Science 2003:302:103-6.

[28] Vinogradova O, Velyvis A, Velyviene A, Hu B, Haas T, Plow E, et al. A structural mechanism of integrin alpha(IIb)beta(3) "inside-out" activation as regulated by its cytoplasmic face. Cell 2002;110:587-97.

[29] Harburger DS, Calderwood DA. Integrin signalling at a glance. J Cell Sci 2009;122: 159-63.

[30] Montanez E, Ussar S, Schifferer M, Bosl M, Zent R, Moser M, et al. Kindlin-2 controls bidirectional signaling of integrins. Genes Dev 2008;22:1325-30.

[31] Moser M, Nieswandt B, Ussar S, Pozgajova M, Fassler R. Kindlin-3 is essential for integrin activation and platelet aggregation. Nat Med 2008;14:325-30.

[32] Lai-Cheong JE, Parsons M, McGrath JA. The role of kindlins in cell biology and relevance to human disease. Int J Biochem Cell Biol 2010;42:595-603.

[33] Kamae T, Shiraga M, Kashiwagi H, Kato H, Tadokoro S, Kurata Y, et al. Critical role of ADP interaction with P2Y12 receptor in the maintenance of alpha(IIb)beta3 activation: association with Rap1B activation. J Thromb Haemost 2006;4:1379-87.

[34] Woulfe D, Jiang H, Mortensen R, Yang J, Brass LF. Activation of Rap1B by G(i) family members in platelets. J Biol Chem 2002;277:23382-90.

[35] Chen YP, O'Toole TE, Ylanne J, Rosa JP, Ginsberg MH. A point mutation in the integrin beta 3 cytoplasmic domain (S752->P) impairs bidirectional signaling through alpha IIb beta 3 (platelet glycoprotein IIb-IIIa). Blood 1994;84:1857-65.

[36] Hughes PE, Diaz-Gonzalez F, Leong L, Wu C, McDonald JA, Shattil SJ, et al. Breaking the integrin hinge. A defined structural constraint regulates integrin signaling. J Biol Chem 1996;271:6571-4.

[37] O'Toole TE, Katagiri Y, Faull RJ, Peter K, Tamura R, Quaranta V, et al. Integrin cytoplasmic domains mediate inside-out signal transduction. J Cell Biol 1994;124:1047-59.

[38] Vinogradova O, Haas T, Plow EF, Qin J. A structural basis for integrin activation by the cytoplasmic tail of the alpha IIb-subunit. Proc Natl Acad Sci U S A 2000;97: $1450-5$

[39] Vinogradova O, Vaynberg J, Kong X, Haas TA, Plow EF, Qin J. Membrane-mediated structural transitions at the cytoplasmic face during integrin activation. Proc Natl Acad Sci U S A 2004:101:4094-9.

[40] Ylanne J, Huuskonen J, O'Toole TE, Ginsberg MH, Virtanen I, Gahmberg CG. Mutation of the cytoplasmic domain of the integrin beta 3 subunit. Differential effects on cell spreading, recruitment to adhesion plaques, endocytosis, and phagocytosis. J Biol Chem 1995;270:9550-7.

[41] Desgrosellier JS, Cheresh DA. Integrins in cancer: biological implications and therapeutic opportunities. Nat Rev Cancer 2010: 9-22. [Review]

[42] Brown EJ, Frazier WA. Integrin-associated protein (CD47) and its ligands. Trends Cell Biol 2001;11:130-5.

[43] Frisch SM, Screaton RA. Anoikis mechanisms. Curr Opin Cell Biol 2001;13: 555-62.

[44] Bissell MJ, Radisky D. Putting tumours in context. Nat Rev Cancer 2001;1:46-54.

[45] Frisch SM, Vuori K, Ruoslahti E, Chan-Hui PY. Control of adhesion-dependent cell survival by focal adhesion kinase. J Cell Biol 1996;134:793-9.

[46] Demers MJ, Thibodeau S, Noel D, Fujita N, Tsuruo T, Gauthier R, et al. Intestinal epithelial cancer cell anoikis resistance: EGFR-mediated sustained activation of Src overrides Fak-dependent signaling to MEK/Erk and/or PI3-K/Akt-1. J Cell Biochem 2009;107:639-54

[47] Shain KH, Landowski TH, Dalton WS. Adhesion-mediated intracellular redistribution of c-Fas-associated death domain-like IL-1-converting enzyme-like inhibitory protein-long confers resistance to CD95-induced apoptosis in hematopoietic cancer cell lines. J Immunol 2002;168:2544-53.

[48] Simpson KJ, Selfors LM, Bui J, Reynolds A, Leake D, Khvorova A, et al. Identification of genes that regulate epithelial cell migration using an siRNA screening approach. Nat Cell Biol 2008;10:1027-38.

[49] Edlund M, Miyamoto T, Sikes RA, Ogle R, Laurie GW, Farach-Carson MC, et al. Integrin expression and usage by prostate cancer cell lines on laminin substrata. Cell Growth Differ 2001;12:99-107.

[50] Yoneda T. Cellular and molecular basis of preferential metastasis of breast cancer to bone. J Orthop Sci 2000;5:75-81.

[51] Clezardin P. Integrins in bone metastasis formation and potential therapeutic implications. Curr Cancer Drug Targets 2009;9:801-6.

[52] van der P, Vloedgraven H, Papapoulos S, Lowick C, Grzesik W, Kerr J, et al. Attachment characteristics and involvement of integrins in adhesion of breast cancer cell lines to extracellular bone matrix components. Lab Invest 1997;77: 665-75.

[53] Liapis H, Flath A, Kitazawa S. Integrin alpha V beta 3 expression by bone-residing breast cancer metastases. Diagn Mol Pathol 1996;5:127-35.

[54] McCabe NP, De S, Vasanji A, Brainard J, Byzova TV. Prostate cancer specific integrin alphavbeta3 modulates bone metastatic growth and tissue remodeling. Oncogene 2007;26:6238-43.

[55] Townsend PA, Villanova I, Uhlmann E, Peyman A, Knolle J, Baron R, et al. An antisense oligonucleotide targeting the alphaV integrin gene inhibits adhesion and induces apoptosis in breast cancer cells. Eur J Cancer 2000;36:397-409.

[56] Gillespie MT, Thomas RJ, Pu ZY, Zhou H, Martin TJ, Findlay DM. Calcitonin receptors, bone sialoprotein and osteopontin are expressed in primary breast cancers. Int J Cancer 1997;73:812-5.

[57] Van der Velde-Zimmermann D, Verdaasdonk MA, Rademakers LH, De Weger RA, Van den Tweel JG, Joling P. Fibronectin distribution in human bone marrow stroma: matrix assembly and tumor cell adhesion via alpha5 beta1 integrin. Exp Cell Res 1997;230:111-20. 
[58] Takayama S, Ishii S, Ikeda T, Masamura S, Doi M, Kitajima M. The relationship between bone metastasis from human breast cancer and integrin alpha(v)beta3 expression. Anticancer Res 2005;25:79-83.

[59] Nakamura I, Duong le T, Rodan SB, Rodan GA. Involvement of alpha(v)beta3 integrins in osteoclast function. J Bone Miner Metab 2007;25:337-44.

[60] Pecheur I, Peyruchaud O, Serre CM, Guglielmi J, Voland C, Bourre F, et al. Integrin alpha(v)beta3 expression confers on tumor cells a greater propensity to metastasize to bone. FASEB J 2002;16:1266-8.

[61] Sloan EK, Pouliot N, Stanley KL, Chia J, Moseley JM, Hards DK, et al. Tumor-specific expression of alphavbeta3 integrin promotes spontaneous metastasis of breast cancer to bone. Breast Cancer Res 2006;8:R20.

[62] Zhao Y, Bachelier R, Treilleux I, Pujuguet P, Peyruchaud O, Baron R, et al. Tumor alphavbeta3 integrin is a therapeutic target for breast cancer bone metastases. Cancer Res 2007;67:5821-30.

[63] Martin-Thouvenin V, Gendron MC, Hogervorst F, Figdor CG, Lanotte M. Phorbol ester-induced promyelocytic leukemia cell adhesion to marrow stromal cells involves fibronectin specific alpha 5 beta 1 integrin receptors. J Cell Physiol 1992;153:95-102.

[64] Korah R, Boots M, Wieder R. Integrin alpha5beta1 promotes survival of growtharrested breast cancer cells: an in vitro paradigm for breast cancer dormancy in bone marrow. Cancer Res 2004;64:4514-22.

[65] Liesveld JL, Dipersio JF, Abboud CN. Integrins and adhesive receptors in normal and leukemic CD34+ progenitor cells: potential regulatory checkpoints for cellular traffic. Leuk Lymphoma 1994;14:19-28.

[66] Lang SH, Clarke NW, George NJ, Testa NG. Primary prostatic epithelial cell binding to human bone marrow stroma and the role of alpha2beta1 integrin. Clin Exp Metastasis 1997;15:218-27.

[67] Hall CL, Dai J, van Golen KL, Keller ET, Long MW. Type I collagen receptor (alpha 2 beta 1) signaling promotes the growth of human prostate cancer cells within the bone. Cancer Res 2006;66:8648-54.

[68] Hall CL, Dubyk CW, Riesenberger TA, Shein D, Keller ET, van Golen KL. Type I collagen receptor (alpha2beta1) signaling promotes prostate cancer invasion through RhoC GTPase. Neoplasia 2008;10:797-803.

[69] Mori Y, Shimizu N, Dallas M, Niewolna M, Story B, Williams PJ, et al. Anti-alpha4 integrin antibody suppresses the development of multiple myeloma and associated osteoclastic osteolysis. Blood 2004;104:2149-54.

[70] Michigami T, Shimizu N, Williams PJ, Niewolna M, Dallas SL, Mundy GR, et al. Cell-cell contact between marrow stromal cells and myeloma cells via VCAM-1 and alpha(4)beta(1)-integrin enhances production of osteoclast-stimulating activity. Blood 2000;96:1953-60.

[71] Matsuura N, Puzon-McLaughlin W, Irie A, Morikawa Y, Kakudo K, Takada Y. Induction of experimental bone metastasis in mice by transfection of integrin alpha 4 beta 1 into tumor cells. Am J Pathol 1996;148:55-61.

[72] Teitelbaum SL, Ross FP. Genetic regulation of osteoclast development and function. Nat Rev Genet 2003;4:638-49.

[73] Ross FP, Teitelbaum SL. alphavbeta3 and macrophage colony-stimulating factor: partners in osteoclast biology. Immunol Rev 2005;208:88-105.

[74] Novack DV, Teitelbaum SL. The osteoclast: friend or foe? Annu Rev Pathol 2008;3:457-84.

[75] Ross FP, Chappel J, Alvarez JI, Sander D, Butler WT, Farach-Carson MC, et al. Interactions between the bone matrix proteins osteopontin and bone sialoprotein and the osteoclast integrin alpha v beta 3 potentiate bone resorption. J Biol Chem 1993;268:9901-7.

[76] McHugh KP. Mice lacking b3 integrins are osteosclerotic because of dysfunctional osteoclasts. J Clin Invest 2000;105:433-40.

[77] Bakewell SJ, Nestor P, Prasad S, Tomasson MH, Dowland N, Mehrotra M, et al. Platelet and osteoclast beta3 integrins are critical for bone metastasis. Proc Natl Acad Sci U S A 2003;100:14205-10.

[78] Zambonin Zallone A, Teti A, Gaboli M, Marchisio PC. Beta 3 subunit of vitronectin receptor is present in osteoclast adhesion structures and not in other monocytemacrophage derived cells. Connect Tissue Res 1989;20:143-9.

[79] Crippes BA, Engleman VW, Settle SL, Delarco J, Ornberg RL, Helfrich MH, et al. Antibody to beta3 integrin inhibits osteoclast-mediated bone resorption in the thyroparathyroidectomized rat. Endocrinology 1996;137:918-24.

[80] Chellaiah MA. Regulation of podosomes by integrin alphavbeta3 and Rho GTPase-facilitated phosphoinositide signaling. Eur J Cell Biol 2006;85:311-7.

[81] Faccio R, Takeshita S, Zallone A, Ross FP, Teitelbaum SL. c-Fms and the alphavbeta3 integrin collaborate during osteoclast differentiation. J Clin Invest 2003;111:749-58

[82] Faccio R, Grano M, Colucci S, Zallone AZ, Quaranta V, Pelletier AJ. Activation of alphav beta3 integrin on human osteoclast-like cells stimulates adhesion and migration in response to osteopontin. Biochem Biophys Res Commun 1998;249: 522-5.

[83] Miyauchi A, Alvarez J, Greenfield EM, Teti A, Grano M, Colucci S, et al. Recognition of osteopontin and related peptides by an alpha $\mathrm{v}$ beta 3 integrin stimulates immediate cell signals in osteoclasts. J Biol Chem 1991;266:20369-74.

[84] Rucci N, DiGiacinto C, Orru L, Millimaggi D, Baron R, Teti A. A novel protein kinase C alpha-dependent signal to ERK1/2 activated by alphaVbeta3 integrin in osteoclasts and in Chinese hamster ovary (CHO) cells. J Cell Sci 2005;118: 3263-75.

[85] Zhang Z, Baron R, Horne WC. Integrin engagement, the actin cytoskeleton, and cSrc are required for the calcitonin-induced tyrosine phosphorylation of paxillin and HEF1, but not for calcitonin-induced Erk1/2 phosphorylation. J Biol Chem 2000;275:37219-23.

[86] Clohisy DR, Ramnaraine ML. Osteoclasts are required for bone tumors to grow and destroy bone. J Orthop Res 1998;16:660-6.
[87] Honore P, Luger NM, Sabino MA, Schwei MJ, Rogers SD, Mach DB, et al. Osteoprotegerin blocks bone cancer-induced skeletal destruction, skeletal pain and pain-related neurochemical reorganization of the spinal cord. Nat Med 2000;6:521-8.

[88] Carlinfante G, Vassiliou D, Svensson O, Wendel M, Heinegard D, Andersson C. Differential expression of osteopontin and bone sialoprotein in bone metastasis of breast and prostate carcinoma. Clin Exp Metastasis 2003;20:437-44.

[89] Heinegard D, Andersson G, Reinholt FP. Roles of osteopontin in bone remodeling. Ann N Y Acad Sci 1995;760:213-22.

[90] Katayama Y, House CM, Udagawa N, Kazama JJ, McFarland RJ, Martin TJ, et al Casein kinase 2 phosphorylation of recombinant rat osteopontin enhances adhesion of osteoclasts but not osteoblasts. J Cell Physiol 1998;176:179-87.

[91] Hayashi C, Rittling S, Hayata T, Amagasa T, Denhardt D, Ezura Y, et al. Serum osteopontin, an enhancer of tumor metastasis to bone, promotes B16 melanoma cell migration. J Cell Biochem 2007;101:979-86.

[92] Denhardt DT, Chambers AF. Overcoming obstacles to metastasis-defenses against host defenses: osteopontin (OPN) as a shield against attack by cytotoxic host cells. J Cell Biochem 1994;56:48-51.

[93] Nemoto H, Rittling SR, Yoshitake H, Furuya K, Amagasa T, Tsuji K, et al Osteopontin deficiency reduces experimental tumor cell metastasis to bone and soft tissues. J Bone Miner Res 2001;16:652-9.

[94] Ohyama Y, Nemoto H, Rittling S, Tsuji K, Amagasa T, Denhardt DT, et al. Osteopontin-deficiency suppresses growth of B16 melanoma cells implanted in bone and osteoclastogenesis in co-cultures. J Bone Miner Res 2004;19: $1706-11$.

[95] Desai B, Rogers MJ, Chellaiah MA. Mechanisms of osteopontin and CD44 as metastatic principles in prostate cancer cells. Mol Cancer 2007;6:18.

[96] Hullinger TG, Taichman RS, Linseman DA, Somerman MJ. Secretory products from PC-3 and MCF-7 tumor cell lines upregulate osteopontin in MC3T3-E1 cells. J Cell Biochem 2000;78:607-16.

[97] Abe M, Hiura K, Wilde J, Shioyasono A, Moriyama K, Hashimoto T, et al Osteoclasts enhance myeloma cell growth and survival via cell-cell contact: a vicious cycle between bone destruction and myeloma expansion. Blood 2004;104:2484-91.

[98] Standal T, Borset M, Sundan A. Role of osteopontin in adhesion, migration, cell survival and bone remodeling. Exp Oncol 2004;26:179-84.

[99] Chen YJ, Wei YY, Chen HT, Fong YC, Hsu CJ, Tsai CH, et al. Osteopontin increases migration and MMP-9 up-regulation via alphavbeta3 integrin, FAK, ERK, and NFkappaB-dependent pathway in human chondrosarcoma cells. J Cell Physiol 2009;221:98-108.

[100] Lundberg P, Koskinen C, Baldock PA, Lothgren H, Stenberg A, Lerner UH, et al Osteoclast formation is strongly reduced both in vivo and in vitro in the absence of CD47/SIRPalpha-interaction. Biochem Biophys Res Commun 2007;352:444-8.

[101] Uluckan O, Becker SN, Deng H, Zou W, Prior JL, Piwnica-Worms D, et al. CD47 regulates bone mass and tumor metastasis to bone. Cancer Res 2009;69: 3196-204.

[102] Han X, Sterling H, Chen Y, Saginario C, Brown EJ, Frazier WA, et al. CD47, a ligand for the macrophage fusion receptor, participates in macrophage multinucleation. J Biol Chem 2000;275:37984-92.

[103] Rachkovsky M, Sodi S, Chakraborty A, Avissar Y, Bolognia J, McNiff JM, et al Melanoma x macrophage hybrids with enhanced metastatic potential. Clin Exp Metastasis 1998;16:299-312.

[104] Vignery A. Macrophage fusion: are somatic and cancer cells possible partners? Trends Cell Biol 2005;15:188-93.

[105] Hanahan D, Weinberg RA. The hallmarks of cancer. Cell 2000;100:57-70.

[106] Stupack DG, Cheresh DA. Integrins and angiogenesis. Curr Top Dev Biol 2004;64: 207-38.

[107] Hood JD, Cheresh DA. Role of integrins in cell invasion and migration. Nat Rev Cancer 2002;2:91-100.

[108] Hodivala-Dilke K. alphavbeta3 integrin and angiogenesis: a moody integrin in a changing environment. Curr Opin Cell Biol 2008;20:514-9.

[109] Silva R, D'Amico G, Hodivala-Dilke KM, Reynolds LE. Integrins: the keys to unlocking angiogenesis. Arterioscler Thromb Vasc Biol 2008;28:1703-13.

[110] Stockmann C, Doedens A, Weidemann A, Zhang N, Takeda N, Greenberg JI, et al. Deletion of vascular endothelial growth factor in myeloid cells accelerates tumorigenesis. Nature 2008;456:814-8.

[111] Morga EA, Schneider J, Uluckan TB, Heller EA, Hurchla MA, et al. Dissection of platelet and myeloid cell defects by conditional targeting of the $\beta 3$ integrin subunit. FASEB J 2010;24:1117-27.

[112] Cackowski FC, Anderson JL, Patrene KD, Choksi RJ, Shapiro SD, Windle JJ, et al Osteoclasts are important for bone angiogenesis. Blood 2010;115:140-9.

[113] Capoccia BJ, Shepherd RM, Link DC. G-CSF and AMD3100 mobilize monocytes into the blood that stimulate angiogenesis in vivo through a paracrine mechanism. Blood 2006;108:2438-45.

[114] De Palma M, Naldini L. Role of haematopoietic cells and endothelial progenitors in tumour angiogenesis. Biochim Biophys Acta 2006;1766:159-66.

[115] Papaspyridonos M, Lyden D. Chapter 11. The role of bone marrow-derived cells in tumor angiogenesis and metastatic progression. Methods Enzymol 2008;444: 255-69.

[116] Ramjaun AR, Hodivala-Dilke K. The role of cell adhesion pathways in angiogenesis. Int J Biochem Cell Biol 2009;41:521-30.

[117] Brooks PC, Clark RA, Cheresh DA. Requirement of vascular integrin alpha v beta 3 for angiogenesis. Science 1994;264:569-71.

[118] Mahabeleshwar GH, Byzova TV. Vascular integrin signaling. Methods Enzymo 2008;443:199-226. 
[119] Brooks PC, Montgomery AM, Rosenfeld M, Reisfeld RA, Hu T, Klier G, et al. Integrin alpha $\mathrm{v}$ beta 3 antagonists promote tumor regression by inducing apoptosis of angiogenic blood vessels. Cell 1994;79:1157-64.

120] Brooks PC, Silletti S, von Schalscha TL, Friedlander M, Cheresh DA. Disruption of angiogenesis by PEX, a noncatalytic metalloproteinase fragment with integrin binding activity. Cell 1998;92:391-400.

[121] Silletti S, Kessler T, Goldberg J, Boger DL, Cheresh DA. Disruption of matrix metalloproteinase 2 binding to integrin alpha vbeta 3 by an organic molecule inhibits angiogenesis and tumor growth in vivo. Proc Natl Acad Sci U S A 2001;98:119-24.

122] Maeshima Y, Yerramalla UL, Dhanabal M, Holthaus KA, Barbashov S, Kharband $\mathrm{S}$, et al. Extracellular matrix-derived peptide binds to alpha(v)beta(3) integrin and inhibits angiogenesis. J Biol Chem 2001;276:31959-68.

[123] Nemeth JA, Cher ML, Zhou Z, Mullins C, Bhagat S, Trikha M. Inhibition of alpha(v) beta3 integrin reduces angiogenesis, bone turnover, and tumor cell proliferation in experimental prostate cancer bone metastases. Clin Exp Metastasis 2003;20: 413-20.

[124] Reynolds LE, Wyder L, Lively JC, Taverna D, Robinson SD, Huang X, et al. Enhanced pathological angiogenesis in mice lacking beta3 integrin or beta3 and beta5 integrins. Nat Med 2002;8:27-34.

[125] Reynolds AR, Reynolds LE, Nagel TE, Lively JC, Robinson SD, Hicklin DJ, et al. Elevated Flk1 (vascular endothelial growth factor receptor 2) signaling mediates enhanced angiogenesis in beta3-integrin-deficient mice. Cancer Res 2004;64: 8643-50.

[126] Carmeliet P. Integrin indecision. Nat Med 2002;8:14-6.

[127] Martin KH, Slack JK, Boerner SA, Martin CC, Parsons JT. Integrin connections map: to infinity and beyond. Science 2002;296:1652-3.

[128] Wang XQ, Sun P, Paller AS. Inhibition of integrin-linked kinase/protein kinase B/ Akt signaling: mechanism for ganglioside-induced apoptosis. J Biol Chem 2001;276:44504-11.

[129] Zhao H, Ross FP, Teitelbaum SL. Unoccupied alpha(v)beta3 integrin regulates osteoclast apoptosis by transmitting a positive death signal. Mol Endocrinol 2005; 19:771-80.

[130] Reynolds AR, Hart IR, Watson AR, Welti JC, Silva RG, Robinson SD, et al Stimulation of tumor growth and angiogenesis by low concentrations of RGDmimetic integrin inhibitors. Nat Med 2009;15:392-400.

[131] Friedlander M, Brooks PC, Shaffer RW, Kincaid CM, Varner JA, Cheresh DA. Definition of two angiogenic pathways by distinct alpha $\mathrm{v}$ integrins. Science 1995;270:1500-2.

[132] Bellahcene A, Chaplet M, Bonjean K, Castronovo V. Zoledronate inhibits alphavbeta3 and alphavbeta5 integrin cell surface expression in endothelial cells. Endothelium 2007; 14:123-30.

[133] Hirbe AC, Roelofs AJ, Floyd DH, Deng H, Becker SN, Lanigan LG, et al. The bisphosphonate zoledronic acid decreases tumor growth in bone in mice with defective osteoclasts. Bone 2009;44:908-16.

[134] Ottewell PD, Monkkonen H, Jones M, Lefley DV, Coleman RE, Holen I. Antitumo effects of doxorubicin followed by zoledronic acid in a mouse model of breast cancer. J Natl Cancer Inst 2008;100:1167-78.

[135] Gao L, Deng H, Zhao H, Hirbe A, Harding J, Ratner L, et al. HTLV-1 Tax transgenic mice develop spontaneous osteolytic bone metastases prevented by osteoclast inhibition. Blood 2005;106:4294-302.

[136] Coleman RE, Guise TA, Lipton A, Roodman GD, Berenson JR, Body JJ, et al. Advancing treatment for metastatic bone cancer: consensus recommendations from the Second Cambridge Conference. Clin Cancer Res 2008;14:6387-95.

[137] Gnant M, Mlineritsch B, Schippinger W, Luschin-Ebengreuth G, Postlberger S, Menzel C, et al. Endocrine therapy plus zoledronic acid in premenopausal breast cancer. N Engl J Med 2009;360:679-91.

[138] Aft R, Naughton M, Trinkaus K, Watson M, Ylagan L, Chavez-MacGregor M, et al Effect of zoledronic acid on disseminated tumour cells in women with locally advanced breast cancer: an open label, randomised, phase 2 trial. Lancet Onco 2010;11:421-8.

[139] Gnant M. The evolving role of zoledronic acid in early breast cancer. Onco Targets Ther 2009;2:95-104.

[140] Tanjore H, Zeisberg EM, Gerami-Naini B, Kalluri R. Beta1 integrin expression on endothelial cells is required for angiogenesis but not for vasculogenesis. Dev Dyn 2008;237:75-82.

[141] Senger DR, Claffey KP, Benes JE, Perruzzi CA, Sergiou AP, Detmar M. Angiogenesis promoted by vascular endothelial growth factor: regulation through alpha1beta1 and alpha2beta1 integrins. Proc Natl Acad Sci U S A 1997;94:13612-7.

[142] Pozzi A, Moberg PE, Miles LA, Wagner S, Soloway P, Gardner HA. Elevated matrix metalloprotease and angiostatin levels in integrin alpha 1 knockout mice cause reduced tumor vascularization. Proc Natl Acad Sci U S A 2000;97:2202-7.

[143] Kim S, Bell K, Mousa SA, Varner JA. Regulation of angiogenesis in vivo by ligation of integrin alpha5beta1 with the central cell-binding domain of fibronectin. Am J Pathol 2000:156:1345-62.

[144] Boudreau NJ, Varner JA. The homeobox transcription factor Hox D3 promotes integrin alpha5beta 1 expression and function during angiogenesis. J Biol Chem 2004;279:4862-8.

[145] Garmy-Susini B, Jin H, Zhu Y, Sung RJ, Hwang R, Varner J. Integrin alpha4beta1VCAM-1-mediated adhesion between endothelial and mural cells is required for blood vessel maturation. J Clin Invest 2005;115:1542-51.

[146] Nikolopoulos SN, Blaikie P, Yoshioka T, Guo W, Giancotti FG. Integrin beta4 signaling promotes tumor angiogenesis. Cancer Cell 2004;6:471-83.

[147] Chung J, Bachelder RE, Lipscomb EA, Shaw LM, Mercurio AM. Integrin (alpha 6 beta 4) regulation of eIF-4E activity and VEGF translation: a survival mechanism for carcinoma cells. J Cell Biol 2002;158:165-74.
[148] Rodriguez-Manzaneque JC, Lane TF, Ortega MA, Hynes RO, Lawler J, Iruela-Arispe ML. Thrombospondin-1 suppresses spontaneous tumor growth and inhibits activation of matrix metalloproteinase- 9 and mobilization of vascular endothelial growth factor. Proc Natl Acad Sci U S A 2001;98:12485-90.

[149] John AS, Rothman VL, Tuszynski GP. Thrombospondin-1 (TSP-1) stimulates expression of integrin alpha6 in human breast carcinoma cells: a downstream modulator of TSP-1-induced cellular adhesion. J Oncol 2010;2010:645376.

[150] Eliceiri BP, Cheresh DA. Adhesion events in angiogenesis. Curr Opin Cell Biol 2001:13:563-8.

[151] Calvi LM, Adams GB, Weibrecht KW, Weber JM, Olson DP, Knight MC, et al. Osteoblastic cells regulate the haematopoietic stem cell niche. Nature 2003;425: 841-6.

[152] Brenner S, Whiting-Theobald N, Kawai T, Linton GF, Rudikoff AG, Choi U, et al. CXCR4-transgene expression significantly improves marrow engraftment of cultured hematopoietic stem cells. Stem Cells 2004;22:1128-33.

[153] Kahn J, Byk T, Jansson-Sjostrand L, Petit I, Shivtiel S, Nagler A, et al. Overexpression of CXCR4 on human CD34+ progenitors increases their proliferation, migration, and NOD/SCID repopulation. Blood 2004;103:2942-9.

[154] Zhang J, Niu C, Ye L, Huang H, He X, Tong WG, et al. Identification of the haematopoietic stem cell niche and control of the niche size. Nature 2003;425: 836-41.

[155] Papayannopoulou T. Mechanisms of stem-/progenitor-cell mobilization: the anti-VLA-4 paradigm. Semin Hematol 2000;37:11-8

[156] Hidalgo A, Peired AJ, Weiss LA, Katayama Y, Frenette PS. The integrin alphaMbeta2 anchors hematopoietic progenitors in the bone marrow during enforced mobilization. Blood 2004:104:993-1001.

[157] Stier S, Ko Y, Forkert R, Lutz C, Neuhaus T, Grunewald E, et al. Osteopontin is a hematopoietic stem cell niche component that negatively regulates stem cell pool size. J Exp Med 2005;201:1781-91.

[158] Christopher MJ, Liu F, Hilton MJ, Long F, Link DC. Suppression of CXCL12 production by bone marrow osteoblasts is a common and critical pathway for cytokine-induced mobilization. Blood 2009;114:1331-9.

[159] Adams GB, Martin RP, Alley IR, Chabner KT, Cohen KS, Calvi LM, et al. Therapeutic targeting of a stem cell niche. Nat Biotechnol 2007;25:238-43.

[160] Mendez-Ferrer S, Frenette PS. Hematopoietic stem cell trafficking: regulated adhesion and attraction to bone marrow microenvironment. Ann N Y Acad Sci 2007;1116:392-413.

[161] Eash KJ, Means JM, White DW, Link DC. CXCR4 is a key regulator of neutrophil release from the bone marrow under basal and stress granulopoiesis conditions. Blood 2009:113:4711-9.

[162] Kollet O, Dar A, Shivtiel S, Kalinkovich A, Lapid K, Sztainberg Y, et al. Osteoclasts degrade endosteal components and promote mobilization of hematopoietic progenitor cells. Nat Med 2006;12:657-64.

[163] Bungartz G, Stiller S, Bauer M, Muller W, Schippers A, Wagner N, et al. Adult murine hematopoiesis can proceed without beta1 and beta7 integrins. Blood 2006;108:1857-64.

[164] Jiang Y, Prosper F, Verfaillie CM. Opposing effects of engagement of integrins and stimulation of cytokine receptors on cell cycle progression of normal human hematopoietic progenitors. Blood 2000;95:846-54

[165] Voura EB, Billia F, Iscove NN, Hawley RG. Expression mapping of adhesion receptor genes during differentiation of individual hematopoietic precursors. Exp Hematol 1997;25:1172-9.

[166] Hemler ME, Lobb RR. The leukocyte beta 1 integrins. Curr Opin Hematol 1995;2: 61-7.

[167] Coulombel L, Auffray I, Gaugler MH, Rosemblatt M. Expression and function of integrins on hematopoietic progenitor cells. Acta Haematol 1997;97:13-21.

[168] Verfaillie CM, McCarthy JB, McGlave PB. Differentiation of primitive human multipotent hematopoietic progenitors into single lineage clonogenic progenitors is accompanied by alterations in their interaction with fibronectin. J Exp Med 1991;174:693-703.

[169] Oostendorp RA, Reisbach G, Spitzer E, Thalmeier K, Dienemann H, Mergenthaler HG, et al. VLA-4 and VCAM-1 are the principal adhesion molecules involved in the interaction between blast colony-forming cells and bone marrow stromal cells. Br J Haematol 1995;91:275-84.

[170] Liesveld JL, Winslow JM, Frediani KE, Ryan DH, Abboud CN. Expression of integrins and examination of their adhesive function in normal and leukemic hematopoietic cells. Blood 1993;81:112-21.

[171] Qian H, Tryggvason K, Jacobsen SE, Ekblom M. Contribution of alpha6 integrins to hematopoietic stem and progenitor cell homing to bone marrow and collaboration with alpha4 integrins. Blood 2006;107:3503-10.

[172] Schreiber TD, Steinl C, Essl M, Abele H, Geiger K, Muller CA, et al. The integrin alpha9beta1 on hematopoietic stem and progenitor cells: involvement in cell adhesion, proliferation and differentiation. Haematologica 2009;94:1493-501.

[173] Yin T, Li L. The stem cell niches in bone. J Clin Invest 2006;116:1195-201.

[174] Kaplan RN, Riba RD, Zacharoulis S, Bramley AH, Vincent L, Costa C, et al. VEGFR1positive haematopoietic bone marrow progenitors initiate the pre-metastatic niche. Nature 2005;438:820-7.

[175] Chavakis E, Aicher A, Heeschen C, Sasaki K, Kaiser R, El Makhfi N, et al. Role of beta2-integrins for homing and neovascularization capacity of endothelial progenitor cells. J Exp Med 2005;201:63-72.

[176] McAllister SS, Gifford AM, Greiner AL, Kelleher SP, Saelzler MP, Ince TA, et al. Systemic endocrine instigation of indolent tumor growth requires osteopontin. Cell 2008;133:994-1005

[177] Lyden D, Hattori K, Dias S, Costa C, Blaikie P, Butros L, et al. Impaired recruitment of bone-marrow-derived endothelial and hematopoietic precursor cells blocks tumor angiogenesis and growth. Nat Med 2001;7:1194-201. 
[178] Pazolli E, Luo X, Brehm S, Carbery K, Chung JJ, Prior JL, et al. Senescent stromalderived osteopontin promotes preneoplastic cell growth. Cancer Res 2009;69: 1230-9.

[179] Wei SC, Tsao PN, Yu SC, Shun CT, Tsai-Wu JJ, Wu CH, et al. Placenta growth factor expression is correlated with survival of patients with colorectal cancer. Gut 2005;54:666-72.

[180] Marcellini M, De Luca N, Riccioni T, Ciucci A, Orecchia A, Lacal PM, et al. Increased melanoma growth and metastasis spreading in mice overexpressing placenta growth factor. Am J Pathol 2006;169:643-54.

[181] Kang Y, Siegel PM, Shu W, Drobnjak M, Kakonen SM, Cordon-Cardo C, et al. A multigenic program mediating breast cancer metastasis to bone. Cancer Cell 2003;3:537-49.

[182] Muller A, Homey B, Soto H, Ge N, Catron D, Buchanan ME, et al. Involvement of chemokine receptors in breast cancer metastasis. Nature 2001;410:50-6.

[183] Sun YX, Fang M, Wang J, Cooper CR, Pienta KJ, Taichman RS. Expression and activation of alpha(v)beta(3) integrins by SDF-1/CXC12 increases the aggressiveness of prostate cancer cells. Prostate 2007;67:61-73.

[184] Sun YX, Wang J, Shelburne CE, Lopatin DE, Chinnaiyan AM, Rubin MA, et al. Expression of CXCR4 and CXCL12 (SDF-1) in human prostate cancers (PCa) in vivo. J Cell Biochem 2003;89:462-73.

[185] Sun YX, Schneider A, Jung Y, Wang J, Dai J, Cook K, et al. Skeletal localization and neutralization of the SDF-1(CXCL12)/CXCR4 axis blocks prostate cancer metastasis and growth in osseous sites in vivo. J Bone Miner Res 2005;20: 318-29.

[186] Smith MC, Luker KE, Garbow JR, Prior JL, Jackson E, Piwnica-Worms D, et al. CXCR4 regulates growth of both primary and metastatic breast cancer. Cancer Res 2004;64:8604-12.

[187] Parmo-Cabanas M, Bartolome RA, Wright N, Hidalgo A, Drager AM, Teixido J. Integrin alpha4beta1 involvement in stromal cell-derived factor-1alpha-promoted myeloma cell transendothelial migration and adhesion: role of cAMP and the actin cytoskeleton in adhesion. Exp Cell Res 2004;294:571-80.

[188] Mahabeleshwar GH, Feng W, Phillips DR, Byzova TV. Integrin signaling is critical for pathological angiogenesis. J Exp Med 2006;203:2495-507.

[189] Feng W, McCabe NP, Mahabeleshwar GH, Somanath PR, Phillips DR, Byzova TV. The angiogenic response is dictated by beta3 integrin on bone marrow-derived cells. J Cell Biol 2008;183:1145-57.

[190] Gabrilovich DI, Nagaraj S. Myeloid-derived suppressor cells as regulators of the immune system. Nat Rev Immunol 2009;9:162-74.

[191] Yang L, Edwards CM, Mundy GR. Gr-1+CD11b+ myeloid-derived suppressor cells: formidable partners in tumor metastasis. J Bone Miner Res 2010;25: 1701-6.

[192] Bingle L, Brown NJ, Lewis CE. The role of tumour-associated macrophages in tumour progression: implications for new anticancer therapies. J Pathol 2002;196:254-65.

[193] Dirkx AE, Oude Egbrink MG, Wagstaff J, Griffioen AW. Monocyte/macrophage infiltration in tumors: modulators of angiogenesis. J Leukoc Biol 2006;80: 1183-96.

[194] Jin H, Su J, Garmy-Susini B, Kleeman J, Varner J. Integrin alpha4beta1 promotes monocyte trafficking and angiogenesis in tumors. Cancer Res 2006;66: 2146-52.

[195] Hume DA. The mononuclear phagocyte system. Curr Opin Immunol 2006;18: 49-53.

[196] Sweet MJ, Hume DA. CSF-1 as a regulator of macrophage activation and immune responses. Arch Immunol Ther Exp (Warsz) 2003;51:169-77.

[197] Sica A, Allavena P, Mantovani A. Cancer related inflammation: the macrophage connection. Cancer Lett 2008;267:204-15.

[198] Gordon S, Taylor PR. Monocyte and macrophage heterogeneity. Nat Rev Immunol 2005;5:953-64.

[199] Martinez FO, Sica A, Mantovani A, Locati M. Macrophage activation and polarization. Front Biosci 2008;13:453-61.

[200] Mantovani A, Sozzani S, Locati M, Allavena P, Sica A. Macrophage polarization: tumor-associated macrophages as a paradigm for polarized M2 mononuclear phagocytes. Trends Immunol 2002;23:549-55.

[201] Chen ZG, Bottazzi B, Wang JM, Mantovani A. Tumor-associated macrophages in metastasizing tumors. Adv Exp Med Biol 1988;233:61-71.

[202] Chambers SK, Kacinski BM, Ivins CM, Carcangiu ML. Overexpression of epithelial macrophage colony-stimulating factor (CSF-1) and CSF-1 receptor: a poor prognostic factor in epithelial ovarian cancer, contrasted with a protective effect of stromal CSF-1. Clin Cancer Res 1997;3:999-1007.

[203] Canioni D, Salles G, Mounier N, Brousse N, Keuppens M, Morchhauser F, et al. High numbers of tumor-associated macrophages have an adverse prognostic value that can be circumvented by rituximab in patients with follicular lymphoma enrolled onto the GELA-GOELAMS FL-2000 trial. J Clin Oncol 2008;26:440-6.

[204] Reyes-Reyes M, Mora N, Gonzalez G, Rosales C. beta1 and beta2 integrins activate different signalling pathways in monocytes. Biochem J 2002;363: 273-80.

[205] Jin H, Aiyer A, Su J, Borgstrom P, Stupack D, Friedlander M, et al. A homing mechanism for bone marrow-derived progenitor cell recruitment to the neovasculature. J Clin Invest 2006;116:652-62.

[206] Sato T, Nakai T, Tamura N, Okamoto S, Matsuoka K, Sakuraba A, et al. Osteopontin/Eta-1 upregulated in Crohn's disease regulates the Th1 immune response. Gut 2005;54:1254-62.

[207] Schneider JG, Zhu Y, Coleman T, Semenkovich CF. Macrophage beta3 integrin suppresses hyperlipidemia-induced inflammation by modulating TNFalpha expression. Arterioscler Thromb Vasc Biol 2007;27:2699-706.
[208] Savill J, Dransfield I, Hogg N, Haslett C. Vitronectin receptor-mediated phagocytosis of cells undergoing apoptosis. Nature 1990;343:170-3.

[209] Savill J, Hogg N, Ren Y, Haslett C. Thrombospondin cooperates with CD36 and the vitronectin receptor in macrophage recognition of neutrophils undergoing apoptosis. J Clin Invest 1992;90:1513-22.

[210] Law DA, DeGuzman FR, Heiser P, Ministri-Madrid K, Killeen N, Phillips DR. Integrin cytoplasmic tyrosine motif is required for outside-in alphallbbeta3 signalling and platelet function. Nature 1999;401:808-11.

[211] Taverna D, Moher H, Crowley D, Borsig L, Varki A, Hynes RO. Increased primary tumor growth in mice null for beta3- or beta3/beta5-integrins or selectins. Proc Natl Acad Sci U S A 2004;101:763-8.

[212] Kanamori M, Kawaguchi T, Berger MS, Pieper RO. Intracranial microenvironment reveals independent opposing functions of host alphaVbeta3 expression on glioma growth and angiogenesis. J Biol Chem 2006;281:37256-64.

[213] Galarneau H, Villeneuve J, Gowing G, Julien JP, Vallieres L. Increased glioma growth in mice depleted of macrophages. Cancer Res 2007;67:8874-81.

[214] Gabrilovich DI, Bronte V, Chen SH, Colombo MP, Ochoa A, Ostrand-Rosenberg S, et al. The terminology issue for myeloid-derived suppressor cells. Cancer Res 2007;67:425 [author reply 426].

[215] Sinha P, Clements VK, Bunt SK, Albelda SM, Ostrand-Rosenberg S. Cross-talk between myeloid-derived suppressor cells and macrophages subverts tumor immunity toward a type 2 response. J Immunol 2007;179:977-83.

[216] Honn KV, Tang DG, Crissman JD. Platelets and cancer metastasis: a causal relationship? Cancer Metastasis Rev 1992;11:325-51.

[217] Billroth T. Pathology and therapeutics, in fifty lectures. Clin Orthop 1871;2003: 4-11.

[218] Gouin-Thibault I, Achkar A, Samama MM. The thrombophilic state in cancer patients. Acta Haematol 2001;106:33-42.

[219] Boucharaba A, Serre CM, Gres S, Saulnier-Blache JS, Bordet JC, Guglielmi J, et al. Platelet-derived lysophosphatidic acid supports the progression of osteolytic bone metastases in breast cancer. J Clin Invest 2004;114:1714-25.

[220] Phillips DR, Charo IF, Scarborough RM. GPIIb-IIla: the responsive integrin. Cell 1991;65:359-62.

[221] Smyth SS, Reis ED, Vaananen H, Zhang W, Coller BS. Variable protection of beta 3 integrin-deficient mice from thrombosis initiated by different mechanisms Blood 2001;98:1055-62.

[222] Hodivala-Dilke KM, McHugh KP, Tsakiris DA, Rayburn H, Crowley D, UllmanCullere $\mathrm{M}$, et al. Beta3-integrin-deficient mice are a model for Glanzmann thrombasthenia showing placental defects and reduced survival. J Clin Invest 1999;103:229-38.

[223] Jurasz P, Stewart MW, Radomski A, Khadour F, Duszyk M, Radomski MW. Role of von Willebrand factor in tumour cell-induced platelet aggregation: differential regulation by NO and prostacyclin. Br J Pharmacol 2001;134:1104-12.

[224] Karpatkin S. Role of thrombin in tumor angiogenesis, implantation, and metastasis. Pathophysiol Haemost Thromb 2003;33(Suppl 1):54-5.

[225] Nierodzik ML, Karpatkin S. Thrombin induces tumor growth, metastasis, and angiogenesis: evidence for a thrombin-regulated dormant tumor phenotype. Cancer Cell 2006;10:355-62.

[226] Nierodzik ML, Plotkin A, Kajumo F, Karpatkin S. Thrombin stimulates tumorplatelet adhesion in vitro and metastasis in vivo. J Clin Invest 1991;87:229-36.

[227] Gasic GJ, Gasic TB, Stewart CC. Antimetastatic effects associated with platelet reduction. Proc Natl Acad Sci U S A 1968;61:46-52.

[228] Izumi Y, Taniuchi Y, Tsuji T, Smith CW, Nakamori S, Fidler IJ, et al Characterization of human colon carcinoma variant cells selected for sialyl Lex carbohydrate antigen: liver colonization and adhesion to vascular endothelial cells. Exp Cell Res 1995;216:215-21.

[229] Kim Y], Borsig L, Varki NM, Varki A. P-selectin deficiency attenuates tumor growth and metastasis. Proc Natl Acad Sci U S A 1998;95:9325-30.

[230] Karpatkin S, Pearlstein E, Ambrogio C, Coller BS. Role of adhesive proteins in platelet tumor interaction in vitro and metastasis formation in vivo. J Clin Invest 1988;81:1012-9.

[231] Lerner WA, Pearlstein E, Ambrogio C, Karpatkin S. A new mechanism for tumor induced platelet aggregation. Comparison with mechanisms shared by other tumor with possible pharmacologic strategy toward prevention of metastases. Int J Cancer 1983;31:463-9.

[232] Nierodzik ML, Bain RM, Liu LX, Shivji M, Takeshita K, Karpatkin S. Presence of the seven transmembrane thrombin receptor on human tumour cells: effect of activation on tumour adhesion to platelets and tumor tyrosine phosphorylation. Br J Haematol 1996;92:452-7.

[233] Mannori G, Crottet P, Cecconi O, Hanasaki K, Aruffo A, Nelson RM, et al. Differential colon cancer cell adhesion to E-, P-, and L-selectin: role of mucin-type glycoproteins. Cancer Res 1995; 55:4425-31.

[234] Bromberg ME, Bailly MA, Konigsberg WH. Role of protease-activated receptor 1 in tumor metastasis promoted by tissue factor. Thromb Haemost 2001;86: $1210-4$.

[235] Camerer E, Qazi AA, Duong DN, Cornelissen I, Advincula R, Coughlin SR. Platelets, protease-activated receptors, and fibrinogen in hematogenous metastasis. Blood 2004;104:397-401.

[236] Francis JL, Amirkhosravi A. Effect of antihemostatic agents on experimental tumor dissemination. Semin Thromb Hemost 2002;28:29-38.

[237] Hu L, Lee M, Campbell W, Perez-Solar R, Karpatkin S. Role of endogenous thrombin in tumor implantation, seeding and spontaneous metastasis. Blood 2004;104:2746-51.

[238] Palumbo JS, Talmage KE, Massari JV, La Jeunesse CM, Flick MJ, Kombrinck KW, et al. Platelets and fibrin(ogen) increase metastatic potential by impeding natural killer cell-mediated elimination of tumor cells. Blood 2005;105:178-85. 
239] Pearlstein E, Ambrogio C, Karpatkin S. Effect of antiplatelet antibody on the development of pulmonary metastases following injection of CT26 colon adenocarcinoma, Lewis lung carcinoma, and B16 amelanotic melanoma tumor cells into mice. Cancer Res 1984;44:3884-7.

[240] Rickles FR, Patierno S, Fernandez PM. Tissue factor, thrombin, and cancer. Chest 2003; $124: 58$ S-68S

[241] Savage B, Almus-Jacobs F, Ruggeri ZM. Specific synergy of multiple substratereceptor interactions in platelet thrombus formation under flow. Cell 1998;94: 657-66.

[242] Shi X, Gangadharan B, Brass LF, Ruf W, Mueller BM. Protease-activated receptors (PAR1 and PAR2) contribute to tumor cell motility and metastasis. Mol Cancer Res 2004:2:395-402.

[243] Amirkhosravi A, Amaya M, Siddiqui FA. Blockade of GpIIb/IIIa inhibits the release of vascular endothelial growth factor (VEGF) from tumor cell-activated platelets and experimental metastasis. Platelets 1999;10:285-92.

[244] Amirkhosravi A, Meyer T, Chang JY, Amaya M, Siddiqui F, Desai H, et al. Tissue factor pathway inhibitor reduces experimental lung metastasis of B16 melanoma. Thromb Haemost 2002;87:930-6.

[245] Rafii DC, Psaila B, Butler J, Jin DK, Lyden D. Regulation of vasculogenesis by platelet-mediated recruitment of bone marrow-derived cells. Arterioscler Thromb Vasc Biol 2008;28:217-22.

[246] Li X, Koh AJ, Wang Z, Soki FN, Park SI, Pienta KJ, et al. Inhibitory effects of megakaryocytic cells in prostate cancer skeletal metastasis. J Bone Miner Res. 2010 [Epub ahead of print]

[247] Beeton CA, Bord S, Ireland D, Compston JE. Osteoclast formation and bone resorption are inhibited by megakaryocytes. Bone 2006;39:985-90.

[248] Grundt A, Grafe IA, Liegibel U, Sommer U, Nawroth P, Kasperk C. Direct effects of osteoprotegerin on human bone cell metabolism. Biochem Biophys Res Commun 2009;389:550-5.

[249] Chollet ME, Brouland JP, Bal dit Sollier C, Bauduer F, Drouet L, Bellucci S. Evidence of a colocalisation of osteoprotegerin (OPG) with von Willebrand factor (VWF) in platelets and megakaryocytes alpha granules. Studies from normal and grey platelets. Br J Haematol 2010;148:805-7.

[250] Leven RM, Tablin F. Extracellular matrix stimulation of guinea pig megakaryocyte proplatelet formation in vitro is mediated through the vitronectin receptor. Exp Hematol 1992;20:1316-22.

[251] Schmitz B, Thiele J, Otto F, Farahmand P, Henze F, Frimpong S, et al. Evidence for integrin receptor involvement in megakaryocyte-fibroblast interaction: a possible pathomechanism for the evolution of myelofibrosis. J Cell Physio 1998;176:445-55.

[252] Lemieux JM, Horowitz MC, Kacena MA. Involvement of integrins alpha(3)beta(1) and alpha(5)beta(1) and glycoprotein IIb in megakaryocyte-induced osteoblast proliferation. J Cell Biochem 2010;109:927-32.

[253] Escudero ND, Lacave M, Ubios AM, Mandalunis PM. Effect of monosodium olpadronate on osteoclasts and megakaryocytes: an in vivo study. J Musculoskelet Neuronal Interact 2009;9:109-20.

[254] Bernasconi S, Matteucci C, Sironi M, Conni M, Colotta F, Mosca M, et al. Effects of granulocyte-monocyte colony-stimulating factor (GM-CSF) on expression of adhesion molecules and production of cytokines in blood monocytes and ovarian cancer-associated macrophages. Int J Cancer 1995;60:300-7.

[255] Zaslavsky A, Baek KH, R.C. Lynch, Short S, Grillo J, Folkman J, et al. Plateletderived thrombospondin-1 is a critical negative regulator and potential biomarker of angiogenesis. Blood 2010;115:4605-13.

[256] Mizejewski GJ. Role of integrins in cancer: survey of expression patterns. Proc Soc Exp Biol Med 1999;222:124-38.

[257] Khalili P, Arakelian A, Chen G, Plunkett ML, Beck I, Parry GC, et al. A non-RGDbased integrin binding peptide (ATN-161) blocks breast cancer growth and metastasis in vivo. Mol Cancer Ther 2006;5:2271-80.

[258] Trikha M, De Clerck YA, Markland FS. Contortrostatin, a snake venom disintegrin, inhibits beta 1 integrin-mediated human metastatic melanoma cell adhesion and blocks experimental metastasis. Cancer Res 1994:54:4993-8.

[259] Ramos OH, Kauskot A, Cominetti MR, Bechyne I, Salla Pontes CL, Chareyre F, et al. A novel alpha(v)beta (3)-blocking disintegrin containing the RGD motive, DisBa-01, inhibits bFGF-induced angiogenesis and melanoma metastasis. Clin Exp Metastasis 2008;25:53-64.

[260] Avraamides CJ, Garmy-Susini B, Varner JA. Integrins in angiogenesis and lymphangiogenesis. Nat Rev Cancer 2008;8:604-17.

[261] Fujii H, Komazawa H, Mori H, Kojima M, Itoh I, Murata J, et al. Antimetastatic activities of synthetic Arg-Gly-Asp-Ser (RGDS) and Arg-Leu-Asp-Ser (RLDS) peptide analogues and their inhibitory mechanisms. Biol Pharm Bull 1995;18:1681-8.
[262] Brooks PC, Stromblad S, Klemke R, Visscher D, Sarkar FH, Cheresh DA. Antiintegrin alpha v beta 3 blocks human breast cancer growth and angiogenesis in human skin. J Clin Invest 1995;96:1815-22.

[263] Vaillant F, Asselin-Labat ML, Shackleton M, Forrest NC, Lindeman GJ, Visvader JE. The mammary progenitor marker CD61/beta3 integrin identifies cancer stem cells in mouse models of mammary tumorigenesis. Cancer Res 2008;68:7711-7.

[264] Feng X, Novack DV, Faccio R, Ory DS, Aya K, Boyer MI, et al. A Glanzmann's mutation in beta 3 integrin specifically impairs osteoclast function. J Clin Invest 2001;107:1137-44.

[265] Putz E, Witter K, Offner S, Stosiek P, Zippelius A, Johnson J, et al. Phenotypic characteristics of cell lines derived from disseminated cancer cells in bone marrow of patients with solid epithelial tumors: establishment of working models for human micrometastases. Cancer Res 1999;59:241-8.

[266] Felding-Habermann B, O'Toole TE, Smith JW, Fransvea E, Ruggeri ZM, Ginsberg $\mathrm{MH}$, et al. Integrin activation controls metastasis in human breast cancer. Proc Natl Acad Sci U S A 2001;98:1853-8.

[267] Teti A, Migliaccio S, Baron R. The role of the alphaVbeta3 integrin in the development of osteolytic bone metastases: a pharmacological target for alternative therapy? Calcif Tissue Int 2002;71:293-9.

[268] Engelman VW. A peptidomimetic antagonists of the avb3 integrin inhibits bone resorption in vitro and prevents osteoporosis in vivo. J Clin Invest 1997;99:2284-92.

[269] Harms JF, Welch DR, Samant RS, Shevde LA, Miele ME, Babu GR, et al. A small molecule antagonist of the alpha(v)beta3 integrin suppresses MDA-MB-435 skeletal metastasis. Clin Exp Metastasis 2004;21:119-28.

[270] Nemeth JA, Nakada MT, Trikha M, Lang Z, Gordon MS, Jayson GC, et al. Alpha-v integrins as therapeutic targets in oncology. Cancer Invest 2007;25:632-46.

[271] Murphy MG, Cerchio K, Stoch SA, Gottesdiener K, Wu M, Recker R. Effect of L000845704, an alphaVbeta3 integrin antagonist, on markers of bone turnover and bone mineral density in postmenopausal osteoporotic women. J Clin Endocrinol Metab 2005;90:2022-8.

[272] Smith JW, Ruggeri ZM, Kunicki TJ, Cheresh DA. Interaction of integrins alpha v beta 3 and glycoprotein IIb-IIla with fibrinogen. Differential peptide recognition accounts for distinct binding sites. J Biol Chem 1990;265:12267-71.

[273] Gramoun A, Shorey S, Bashutski JD, Dixon SJ, Sims SM, Heersche JN, et al. Effects of Vitaxin, a novel therapeutic in trial for metastatic bone tumors, on osteoclast functions in vitro. J Cell Biochem 2007;102:341-52.

[274] Hariharan S, Gustafson D, Holden S, McConkey D, Davis D, Morrow M, et al. Assessment of the biological and pharmacological effects of the alpha nu beta3 and alpha nu beta5 integrin receptor antagonist, cilengitide (EMD 121974), in patients with advanced solid tumors. Ann Oncol 2007:18:1400-7.

[275] Oliveira-Ferrer L, Hauschild J, Fiedler W, Bokemeyer C, Nippgen J, Celik I, et al. Cilengitide induces cellular detachment and apoptosis in endothelial and glioma cells mediated by inhibition of FAK/src/AKT pathway. J Exp Clin Cancer Res 2008;27:86.

[276] Legler DF, Wiedle G, Ross FP, Imhof BA. Superactivation of integrin alphavbeta3 by low antagonist concentrations. J Cell Sci 2001;114:1545-53.

[277] Alghisi GC, Ponsonnet L, Ruegg C. The integrin antagonist cilengitide activates alphaVbeta3, disrupts VE-cadherin localization at cell junctions and enhances permeability in endothelial cells. PLoS One 2009;4:e4449.

[278] Guo W, Giancotti FG. Integrin signalling during tumour progression. Nat Rev Mol Cell Biol 2004;5:816-26.

[279] Sterling JA, Edwards JR, Martin TJ, Mundy GR. Advances in the biology of bone metastasis: how the skeleton affects tumor behavior. Bone. 2010 [Epub ahead of print]

[280] Bisanz K, Yu J, Edlund M, Spohn B, Hung MC, Chung LW, et al. Targeting ECMintegrin interaction with liposome-encapsulated small interfering RNAs inhibits the growth of human prostate cancer in a bone xenograft imaging model. Mol Ther 2005;12:634-43.

[281] Danen EH, Marcinkiewicz C, Cornelissen IM, van Kraats AA, Pachter JA, Ruiter DJ, et al. The disintegrin eristostatin interferes with integrin alpha 4 beta 1 function and with experimental metastasis of human melanoma cells. Exp Cell Res 1998:238:188-96.

[282] Nervi B, Ramirez P, Rettig MP, Uy GL, Holt MS, Ritchey JK, et al. Chemosensitization of acute myeloid leukemia (AML) following mobilization by the CXCR4 antagonist AMD3100. Blood 2009;113:6206-14.

[283] Lane SW, Scadden DT, Gilliland DG. The leukemic stem cell niche: current concepts and therapeutic opportunities. Blood 2009;114:1150-7.

[284] Azab AK, Runnels JM, Pitsillides C, Moreau AS, Azab F, Leleu X, et al. CXCR4 inhibitor AMD3100 disrupts the interaction of multiple myeloma cells with the bone marrow microenvironment and enhances their sensitivity to therapy. Blood 2009;113: 4341-51. 